\title{
アースドリルエ法で用いる掘削安定液に含まれる懸濁物への 重金属等の吸着に関する研究
}

\author{
1 長谷工コーポレーション \\ 2 京都大学大学院地球環境学堂
}

中村 光男 $^{1}$, 勝見 武 $^{2}$

\section{概 要}

土壤・地下水污染の存在する地盤に杭を計画する場合，杭は污染土層とその下の難透水層を貫通して支 持層に達するが，このような杭の施工によって難透水層の下部の帯水層に污染物質を拡散させるおそれが ある。污染物質の拡散を防止するための杭工法は，いくつか実績があるものの合理的な工法として確立さ れていないのが現状である。そこで，アースドリル工法で用いる安定液に含まれるべントナイトなどの懸 濁物に重金属を吸着させ, 污染物質の拡散防止を図る工法について実験的に検討をおこなった。その結果, アースドリル工法で用いる安定液に含まれる懸濁物は，鉛に対して高い吸着機能を有することが明らかに なった。また，安定液に吸着材を添加し適切な施工管理を行えば，ヒ素，フッ素，鉛に対して高い吸着機 能を持たせることが可能であり，自然由来程度の污染土畩であれば，この安定液の適用が污染物質の拡散 防止対策となる可能性を示した。

キーワード：重金属等，地盤污染，場所打ち杭，アースドリル，安定液

\section{1. はじめに}

土壌污染地に住宅を計画する際, その対策のほとんどが 掘削除去である。工事が短期間で済むこと, 污染土壤が残 らないので入居者に説明しやすいこと, 周辺住民一の説明 がしやすいことがその理由である。とりわけ住宅購入者に 分譲するような, いわゆる分譲集合住宅の場合はそうした 『ゼロリスク』を求める傾向が強い。集合住宅分譲事業に おいて全面的な掘削除去以外の措置を実施した事例は少 なく, 土壌污染対策法の制定（2002 年）以降に筆者が携 わった対策工事 40 物件（関西地区）の内訳は，掘削除去 が 39 件で原位置浄化は 1 件しかない。また，掘削除去に は自然由来の重金属等污染土壤も多く含まれる。しかしな がら掘削除去, 特に場外処分を行うには多額の費用がかか るだけでなく, 污染土とその埋め戻し材の運搬による周辺 環境の悪化, 搬出先である埋立て処分場の受け入れ容量の 逼迫，不法投棄など，環境への負荷も極めて大きい。

2009 年に土壌污染対策法が比較的大きく改正され, 污 染の除去だけでなく暴露経路の遮断も有効な対策として 法律で認められた。この法改正によって, 今後は掘削除去 による完全浄化に代わり, 污染は残るものの, 人の健康被 害が生じないように適切にリスク管理しながら, 土壌污染 地の有効活用を図るケースが増えてくると期待された。し かしながら, 環境省による調査結果によると, 改正法施行 直後の 2010 年度の要措置区域および形質変更時要届出区 域における措置については，掘削除去が 164 件中 133 件 （81\%）と 2009 年度までと同様に多く採用されている。
法の趣旨に則り, 人の健康被害が生じないように適切にリ スク管理しながら土壌污染地の利活用を図ることのでき

る, 安全かつ経済的な対策技術が求められている。

特に 2009 年の法改正では, 自然由来により污染された 土壤も法の対象となった。自然由来の污染土䁃は, 人為由 来に比べて低濃度で万遍なく分布することが特徵である。 このような自然由来の污染土壤に対して, 過剩な対応をす ることは, 工事コストの大幅な増加につながるため, 低濃 度の自然由来污染に適した, 安価で必要最小限の効果が得 られる工法・技術が求められている。

\section{2. 污染地盤への杭打設に関する課題}

\section{土歵污染地を集合住宅として有效活用する際には基礎}

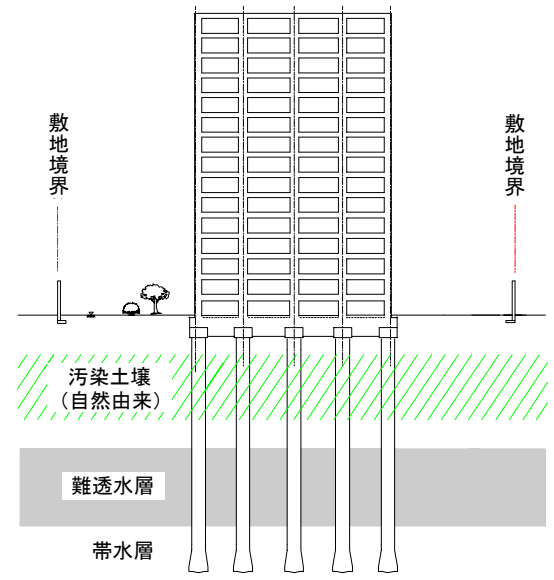

図 1 污染を存置し集合住宅を建設する場合の概念図 
杭が必要となることが多い。図 1 に示すように污染土壤・ 地下水の存在する地盤に杭を計画する場合, 杭は污染土層 とその下の難透水層を貫通して支持層に達する。このよう な杭の施工によって污染土層に存在寸る污染土壌・地下水 を難透水層下部の帯水層に拡散させるおそれがある。

\section{1 污染土層および難透水層を貫通する杭の現状}

污染土層とその下の難透水層を貫通する杭を設置する 工法については, 環境省『土壌污染対策法に基づく調查及 び措置に関するガイドライン (改訂第 2 版)』に, 以下の 施工方法が示されている。

1）杭打設範囲の全体を囲むように遮水壁を設置し，基準 不適合土壤及び地下水を掘削・揚水等により除去した 上で杭を打設する。(図 2a)

2) 杭よりも一回り大きいケーシングを不透水層まで設置 し，基準不適合土袞及び地下水を掘削・揚水等により 除去した上で杭を打設する。(図 2b)

3）杭よりも一回り大きいケーシングを不透水層まで設置 し, ケーシング内に不透水層を構築した後, 杭を打設 寸る。(図 2c)

これらは基本的に人為由来による污染を想定しており，い ずれの施工手順も通常の杭打設工事に比べ工事費の大幅 な増額と, 工期の延伸が生じている。また, 図 $2 \mathrm{~b}$ や図 $2 \mathrm{c}$ で準不透水層までの深さが $10 \mathrm{~m}$ を超える場合, 内部の掘 削の併用なしにケーシングの設置は困難であることなど, 問題が多い。

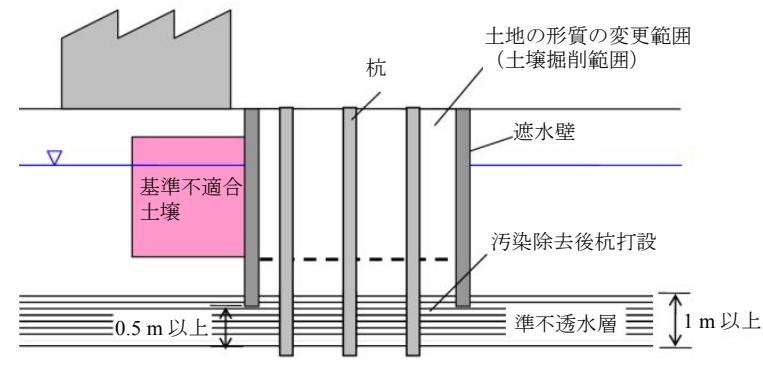

a 遮水壁を設置する場合
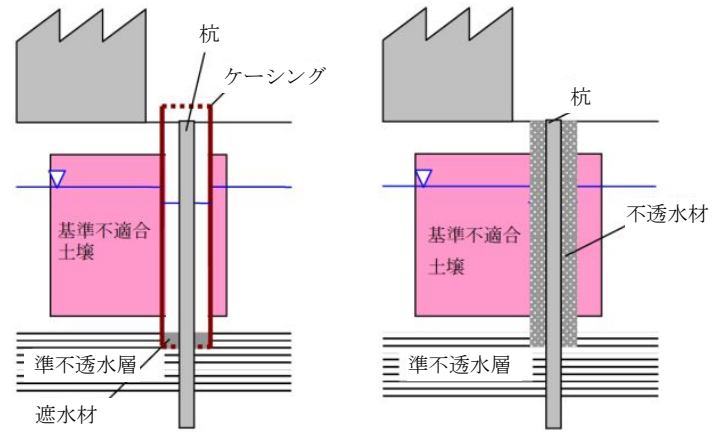

b ケーシングを設置する場合

c 不透水層を構築する場合

図 2 形質の変更の届出を要しない行為の施工方法 ${ }^{1)}$

\section{2 管理型廃棄物処分場跡地への杭打設}

本論文が対象とする自然由来の污染地盤とは異なるが, 上野 ${ }^{2}$ (管理型廃棄物処分場として埋め立てが行なわれ た土地に基礎杭を打設した事例を報告している。東京港臨
海道路建設に伴い, 厚さ約 12〜13 m の廃衰物層とその下 に遮水層が $20 \mathrm{~m}$ 以上堆積した地盤に基礎杭（鋼管杭）を 打設している。支持層は遮水層下部にあるため, 杭は粘性 土層を貫通することになる。したがって廃棄物の引き込み による遮水層への移動や, 杭と遮水層との間に水みちが発 生し, 廃棄物からの浸出水の遮水層への移動が懸念された。 このような污染拡散の防止を目的に, 廃棄物を取り除いた 状態で杭を打設できるよう「三重管基礎杭工法」で施工さ れている。

管理型廃棄物処分場の底面遮水層を貫通寸る基礎杭の 打設が，底面遮水層の遮水性能に与える影響については， 多くの研究がなされている。嘉門ら ${ }^{3)}$ は鋼管杭と粘土地盤 の境界面における漏水量, 透水特性を評価し, 杭打設によ る環境影響を評価するための実験的検討を実施し，その結 果，粘土と金属面の空隙は粘土地盤が正規圧密状態，もし くは弱い過圧密状態であれば粘土地盤の圧密変形により 閉塞する。したがって，底部遮水層である粘性地盤に基礎 杭を打設した場合，その環境影響は許容できる水準である としている。菊池ら ${ }^{4}$ は廃棄物層と遮水基盤を貫通するよ うな杭を打設することが廃棄物を由来とする物質の処分 場外への漏出に及ぼす影響について, 杭打設時と杭打設後 の課題に分けて検討した。その結果，杭と粘土との境界面 の透水性は非常に低く, 粘性土地盤から保有水の漏出の可 能性はきわめて低いとした。また，地震時の杭と地盤との 剥離による保有水の拡散に及ぼす影響は小さいとした。さ らに, 漏出を低減できる工法についても検討し，杭打設時 に粘性土地盤の遮水性能一の影響が少ないのは, 鋼管杭や PHC 杭で，施工方法は打撃工法や中堀工法および回転打 設であるとしている。

以上のことから，適切な設計・施工を行えば，杭の打設 によって污染物質を拡散させることはないと考えられ, 施 工実績もいくつか存在する。しかしながら，通常の杭打設 工事に比べ工事費の大幅な増額と，工期の延伸が発生して いるのが現状であり，これらの対策工法が，比較的低い濃 度の自然由来の污染土壌に対して合理的であるとは言い 難い。

\section{3 研究の目的}

中高層集合住宅（7 15 階建て）の基礎杭工法について は，地盤条件や上部構造にもよるが，一般的に既製杭（鋼 管杭，既製コンクリート杭）よりも場所打ちコンクリート 杭，中でもアースドリル工法が経済的で，最も多く採用さ れている。ところが，この経済的かつ採用実績の最も多い アースドリル工法による場所打ちコンクリート杭が, 污染 地盤に与える影響に関する研究は少ない。

そこで, 本研究では, 污染物質の拡散を防止し, 経済性 を有する場所打ち杭打設工法を見出すことを目的として 実験的に検討を行った。まず，污染地盤をアースドリル工 法で掘削し場所打ち杭を構築する際, 安定液に重金属等が 混入するが，このときの安定液に含まれるベントナイトや 細粒土などの懸濁物（以下，安定液懸濁物）による重金属 
等の吸着機能を明らかにした。また, 安定液の混和材とし て重金属吸着材を添加し, ヒ素, フッ素, 鉛それぞれの濃 度を基準值未満に低減するための配合について検討を行 った。これらの実験では, 安定液にヒ素, フッ素, 鉛を混 合・擋拌・ ろ過し，ろ液の重金属等の濃度を測定した。吸 着効果の評価は地下水環境基準との比較により行った。さ らに本工法の実現場への適用に関して, 安定液懸濁物によ る重金属の吸着機構を踏まえた安定液の配合設計手法, 施 工管理手法ならびにコスト効果について考察した。

\section{3. 安定液懸濁物による重金属等吸着機能の検証}

\section{1 安定液懸濁物による重金属等吸着について}

アースドリル工法は場所打ち杭の掘削工法の一つで, ド リリングバケットを回転させて地盤を掘削し, バケット内 部に格納した土砂を地上に排出する工法である。（図 3） 孔壁は表層部では表層ケーシングを用い, それ以深は安定 液で保護する。掘削完了後, 所定の形状に製作された鉄筋 かごを建込み, トレミー管でコンクリートを打設し杭を築 造する。安定液には対象とする地盤の性状に合わせてベン トナイト系またはポリマー系安定液が用いられる。安定液 に求められる機能とこれに必要な性質を図 4 に示す。

アースドリル工法で地盤を掘削する際, 孔壁の崩壊を防 ぐために常に地下水位プラス $2.0 \mathrm{~m}$ 以上の水頭差を維持す る。そのため污染土層の掘削過程では外部からの污染物質 の侵入は考えにくいが, 安定液には掘削土に含まれる有害

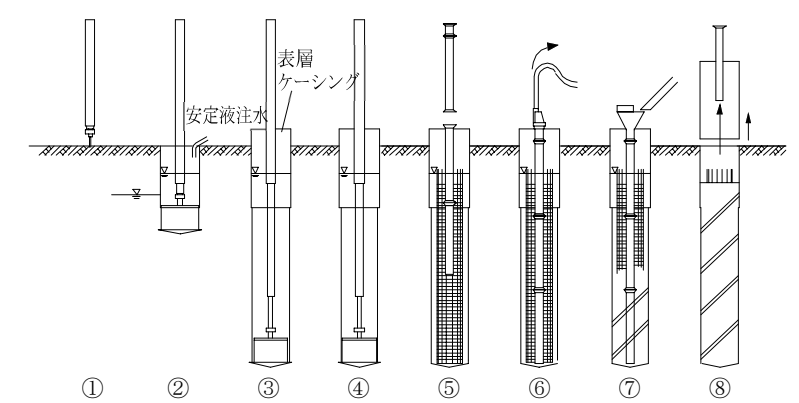

(1) 杭芯合わせ

(2) 掘削開始 安定液注入開始

(5) 鉄筋かご建込み〜トレミー建込み

(3) 表層ケーシング建込み〜掘削完了

(4) 一次孔底処理（底ざらい）

(6) 二次孔底処理（ポンプリフト）

(7) コンクリート打込み

(8) 表層ケーシング撤去〜トレミー撤去

図 3 アースドリル工法による杭工事施工要領図 ${ }^{5)}$

\section{安定液の使用目的（機能）}

(1) 崩壊防止

(2) スライム （主に砂分）

(3) コンクリートとの置換性 (微粒子分)

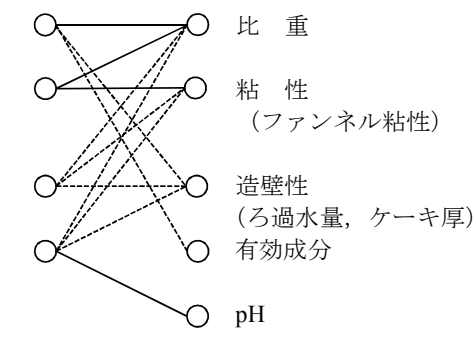

○一○ 大きい程, または多い程有効に機能する。

○-------○小さい程, または少ない程有効に機能する。

$<$ 注 $>$ 孔内水位 $>$ 地下水位が崩壊防止に必要。

図 4 安定液の機能と必要な性質9)
物質が混入する。この安定液を用いて掘削を継続し粘土層 を貫通したとき, 粘土層下部の帯水層へ污染物質を漏出す るおそれがある。一方で, 安定液懸濁物には重金属等に対 する吸着能力を持つことが知られており ${ }^{778) 9910)}$, 漏出して も問題のない程度まで重金属等の濃度が低減される可能 性がある。もし安定液懸濁物が, 混入した重金属等を吸着 し, その溶出量が土壤溶出量基準未満であれば, 粘土層下 部帯水層への污染物質の拡散は起こりにくいと考えられ る。よって本章では, 安定液懸濁物そのものが有する重金 属吸着機能について実験的に検証した。

\section{2 実験方法}

図 5 に示すように，ヒ素( $\mathrm{As})$, フッ素 $(\mathrm{F})$, 鉛 $(\mathrm{Pb})$ に対す る安定液懸濁物の吸着機能を検証するため, バッチ吸着試 験および図 6 に示す API 規格（アメリカ石油協会）の加 圧ろ過試験器を用いてろ過試験を行った。ろ過試験は, 泥 膜によるろ過効果を模擬している。また, 重金属等の混入 による安定液の性状の変化を確認するため, 同時に安定液 の理化学特性の評価を行った。評価項目と基準值を表 1 に示す。実験手順を以下に示す。

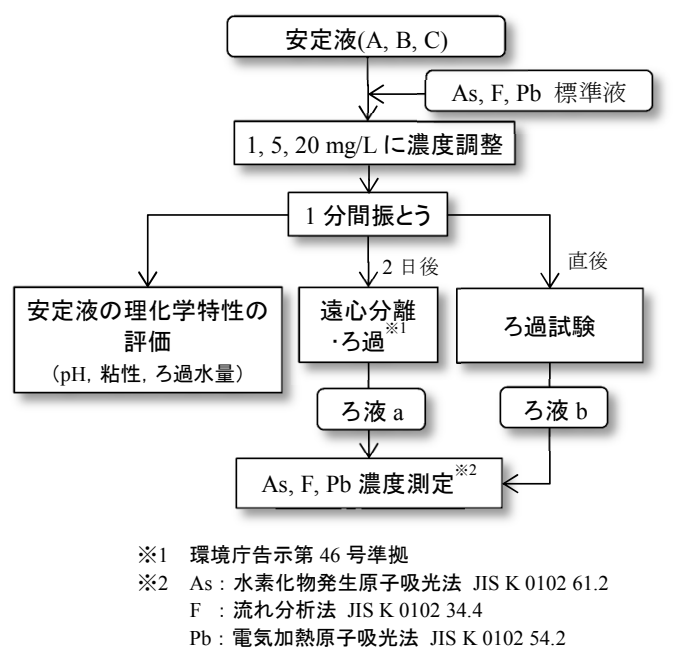

図 5 実験フロー

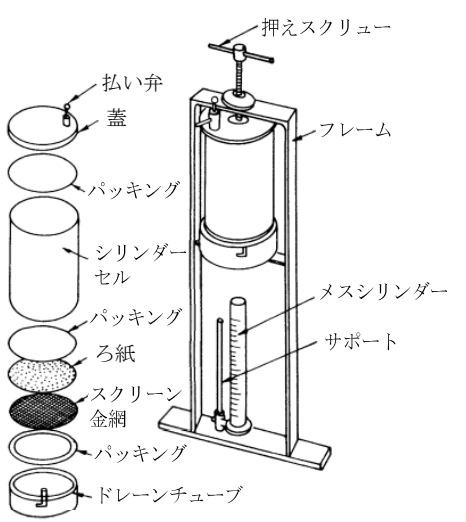

図 6 加圧万過試験器 ${ }^{11}$

表 1 安定液の性状評価項目と管理基淮值 ${ }^{12)}$

\begin{tabular}{l|c|c}
\hline \multicolumn{1}{c|}{ 評価項目 } & 単位 & 基淮値 \\
\hline ファンネル粘性 & $\mathrm{s}$ & $20 \sim 40$ \\
ろ過水量 & $\mathrm{ml}$ & 20 以下 \\
$\mathrm{pH}$ & - & $8 \sim 12$ \\
\hline
\end{tabular}


1）安定液は一般に使用されている A ポリマー系安定液, Bベントナイト系安定液および大阪市内の施工中現場で サンプリングした C 現場採取安定液の 3 種類を使用した。 安定液 A, B は作液後 24 時間の養生を行った。安定液の 配合を表 2 に示す。また, 実験に使用したベントナイト (浅間) のX 線回折分析結果を表 3 に示す。

2) 対象重金属等 ( $\mathrm{As}, \mathrm{F}, \mathrm{Pb}$ ) は原子吸光分析用の 1,000 $\mathrm{mg} / \mathrm{L}$ 標準液 $\left(\mathrm{As}_{2} \mathrm{O}_{3}, \mathrm{~F}^{-}, \mathrm{Pb}\left(\mathrm{NO}_{3}\right)_{2}\right.$ すべて和光純薬工業製 $)$ を安定液 $1 \mathrm{~L}$ 当りにそれぞれ $1,5,20 \mathrm{mg} / \mathrm{L}$ の濃度になる ように 3 水準で添加し, 1 分間の振とうを行った。各物 質の相互作用を確認するために，2 種混合溶液（As+F， $\mathrm{As}+\mathrm{Pb}, \mathrm{F}+\mathrm{Pb})$ および 3 種混合溶液（ $\mathrm{As}+\mathrm{F}+\mathrm{Pb})$ も作成 した。

3) 安定液の振とう後, 直ちに図 6 に示す加圧ろ過試験器 を用いてろ過 (ろ過圧 $0.5 \mathrm{MPa}$, 万紙の保留粒子径 $1 \mu \mathrm{m}$ ) を行い, 得られたろ液 b の As, F, Pb 濃度を測定した。
表 2 安定液 $A, B, C$ 成分表

\begin{tabular}{lccc}
\hline \multicolumn{1}{c}{ 安定液成分 } & $\begin{array}{c}\mathrm{A} \\
\text { ポリマー系 }\end{array}$ & $\begin{array}{c}\mathrm{B} \\
\text { ベントナイト系 }\end{array}$ & $\begin{array}{c}\mathrm{C} \\
\text { 現場採取 }\end{array}$ \\
\hline ベントナイト（浅間\#300) & 1.5 & 8.0 & 5.0 \\
$\mathrm{CMC}$ ( DKS ポリマー280) & 0.3 & 0.05 & 0.2 \\
分散剤 (マーゼル SH) & 0.1 & 0.1 & 0.1 \\
$\mathrm{pH}$ 調整剤 (ソーダ灰) & 0.1 & 0.1 & 0.1 \\
粘土分 & 0.0 & 5.0 & 1.5 \\
\hline & & & 単位\%
\end{tabular}

表 3 ベントナイト (浅間) X 線回折試験結果

\begin{tabular}{|c|c|c|}
\hline \multicolumn{2}{|c|}{ 鉱物名 } & 相対強度 \\
\hline モンモリロナイト & Montmorillonite & +++ \\
\hline 石英 & $\alpha$-Quartz & +++ \\
\hline 斜プチロル沸石 & Clinoptilolite & + \\
\hline カルサイト & Calcite & + \\
\hline マグネタイト & Magnetite & $(+)$ \\
\hline バラー沸石 & Barrerite & $(+)$ \\
\hline
\end{tabular}
測定装置: PANalytical 製 X 線回折装 X'置 Xert PRO

表 4 吸着試験結果（安定液 $\mathrm{A} ：$ ポリマー系安定液）

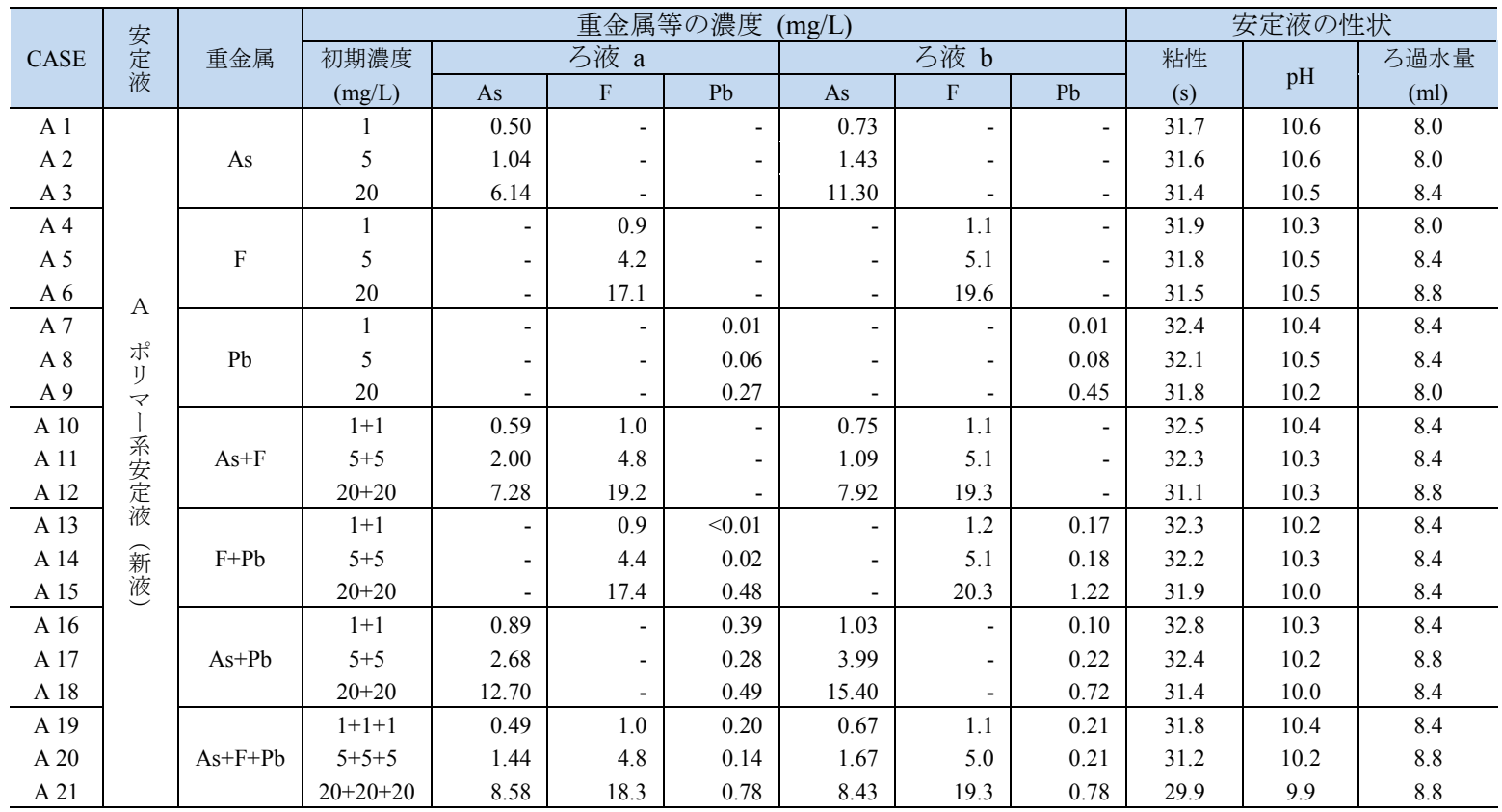

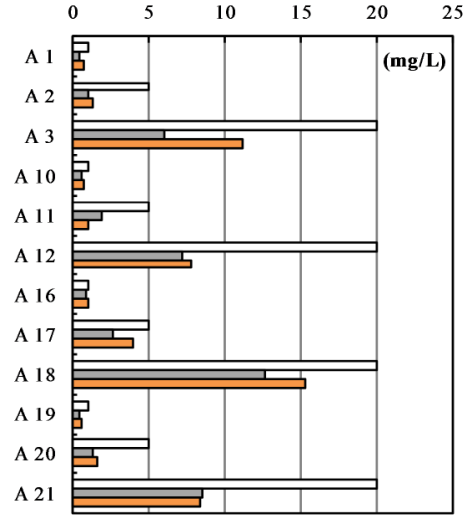

(a) As 濃度

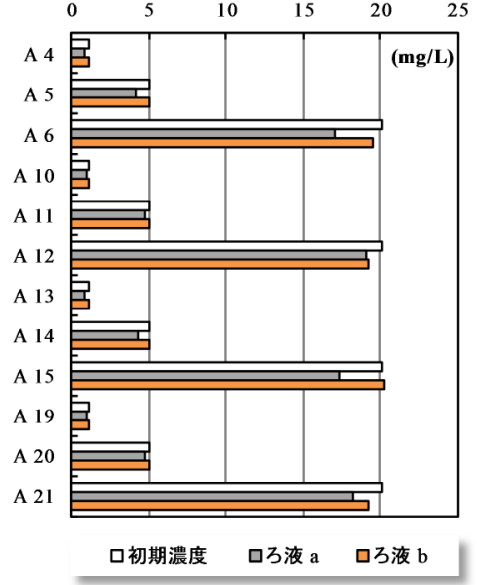

(b) $\mathrm{F}$ 濃度

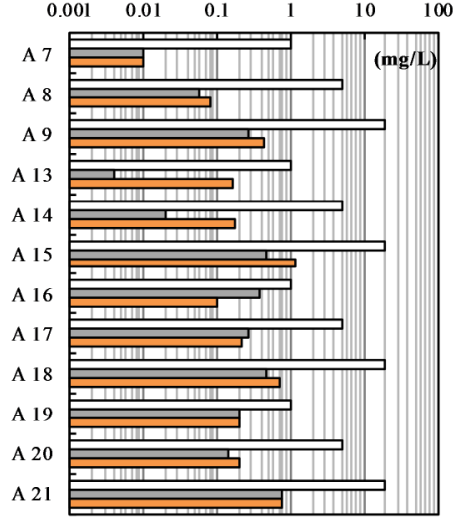

(c) $\mathrm{Pb}$ 裖度

図 7 重金属等吸着試験結果（安定液 $\mathrm{A}$ ) 
表 5 吸着試験結果（安定液 B : ベントナイト系安定液）

\begin{tabular}{|c|c|c|c|c|c|c|c|c|c|c|c|c|}
\hline \multirow{3}{*}{ CASE } & \multirow{3}{*}{$\begin{array}{l}\text { 安 } \\
\text { 定 } \\
\text { 液 }\end{array}$} & \multirow{3}{*}{ 重金属 } & \multicolumn{7}{|c|}{ 重金属等の濃度 $(\mathrm{mg} / \mathrm{L})$} & \multicolumn{3}{|c|}{ 安定液の性状 } \\
\hline & & & \multirow{2}{*}{$\begin{array}{c}\text { 初期濃度 } \\
(\mathrm{mg} / \mathrm{L})\end{array}$} & \multicolumn{3}{|c|}{ 万液 $\mathrm{a}$} & \multicolumn{3}{|c|}{ 万液 $\mathrm{b}$} & \multirow{2}{*}{$\begin{array}{c}\text { 粘性 } \\
\text { (s) }\end{array}$} & \multirow{2}{*}{$\mathrm{pH}$} & \multirow{2}{*}{$\begin{array}{c}\text { 万過水量 } \\
(\mathrm{ml})\end{array}$} \\
\hline & & & & As & $\mathrm{F}$ & $\mathrm{Pb}$ & As & $\mathrm{F}$ & $\mathrm{Pb}$ & & & \\
\hline B 1 & \multirow[b]{6}{*}{ B } & \multirow{3}{*}{ As } & 1 & 0.34 & - & - & 0.37 & - & - & 26.8 & 9.8 & 8.0 \\
\hline B 2 & & & 5 & 1.73 & - & - & 1.98 & - & - & 26.3 & 9.8 & 8.0 \\
\hline B 3 & & & 20 & 2.46 & - & - & 3.48 & - & - & 26.1 & 9.8 & 8.0 \\
\hline B 4 & & \multirow{3}{*}{$\mathrm{F}$} & 1 & - & 1.2 & - & - & 1.3 & - & 26.2 & 9.7 & 8.0 \\
\hline B 5 & & & 5 & - & 4.1 & - & - & 4.8 & - & 26.3 & 9.9 & 8.0 \\
\hline B 6 & & & 20 & - & 15.7 & - & - & 17.0 & - & 26.1 & 9.8 & 8.0 \\
\hline B 7 & ベ & \multirow{3}{*}{$\mathrm{Pb}$} & 1 & - & - & 0.01 & - & - & 0.01 & 26.7 & 9.8 & 8.4 \\
\hline B 8 & ン & & 5 & - & - & 0.04 & - & - & 0.02 & 26.8 & 9.6 & 8.4 \\
\hline B 9 & F & & 20 & - & - & 0.18 & - & - & 0.13 & 26.9 & 9.2 & 8.4 \\
\hline B 10 & イ & \multirow{3}{*}{$\mathrm{As}+\mathrm{F}$} & $1+1$ & 0.35 & 1.3 & - & 0.33 & 1.5 & - & 27.2 & 9.6 & 8.4 \\
\hline B 11 & 采 & & $5+5$ & 1.41 & 4.7 & - & 1.48 & 5.0 & - & 27.6 & 9.7 & 8.0 \\
\hline B 12 & 劣 & & $20+20$ & 11.20 & 15.7 & - & 10.30 & 17.1 & - & 27.1 & 9.6 & 8.0 \\
\hline B 13 & 定 & \multirow{3}{*}{$\mathrm{F}+\mathrm{Pb}$} & $1+1$ & - & 1.3 & $<0.01$ & - & 1.4 & $<0.01$ & 27.4 & 9.7 & 8.0 \\
\hline B 14 & \multirow{8}{*}{$\begin{array}{l}\text { 新 } \\
\text { 液 }\end{array}$} & & $5+5$ & - & 4.3 & 0.03 & - & 1.9 & 0.01 & 27.3 & 9.7 & 7.6 \\
\hline B 15 & & & $20+20$ & - & 14.1 & 0.15 & - & 16.4 & 0.17 & 26.5 & 9.0 & 7.2 \\
\hline B 16 & & \multirow{3}{*}{$\mathrm{As}+\mathrm{Pb}$} & $1+1$ & 0.33 & - & 0.04 & 0.32 & - & 0.02 & 27.4 & 9.5 & 8.4 \\
\hline B 17 & & & $5+5$ & 0.94 & - & 0.04 & 1.32 & - & 0.04 & 27.1 & 9.7 & 8.0 \\
\hline B 18 & & & $20+20$ & 4.50 & - & 0.12 & 4.26 & - & 0.10 & 26.9 & 9.4 & 7.6 \\
\hline В 19 & & \multirow{3}{*}{$\mathrm{As}+\mathrm{F}+\mathrm{Pb}$} & $1+1+1$ & 0.38 & 1.3 & 0.02 & 0.29 & 1.4 & 0.02 & 27.9 & 9.7 & 8.4 \\
\hline B 20 & & & $5+5+5$ & 1.13 & 4.0 & 0.04 & 1.48 & 5.0 & 0.03 & 28.1 & 9.5 & 8.0 \\
\hline B 21 & & & $20+20+20$ & 11.30 & 13.3 & 0.18 & 10.20 & 16.2 & 0.14 & 27.0 & 9.3 & 8.0 \\
\hline
\end{tabular}

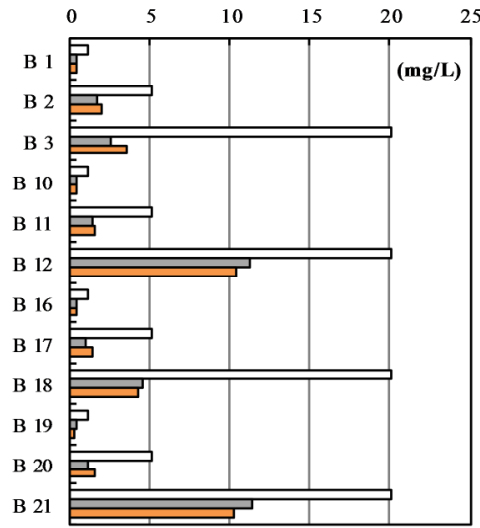

(a) As 濃度

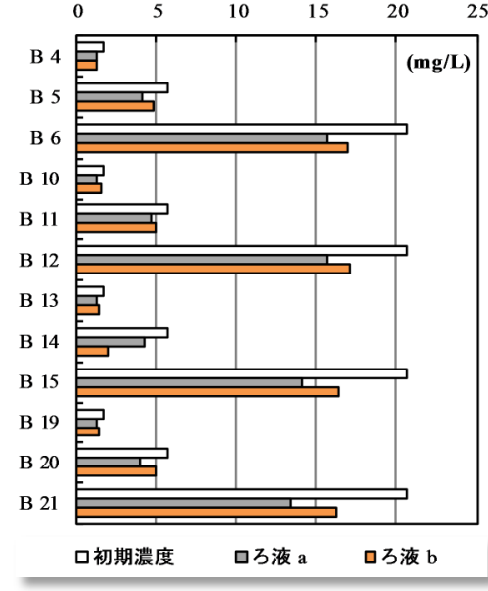

(b) $\mathrm{F}$ 濃度

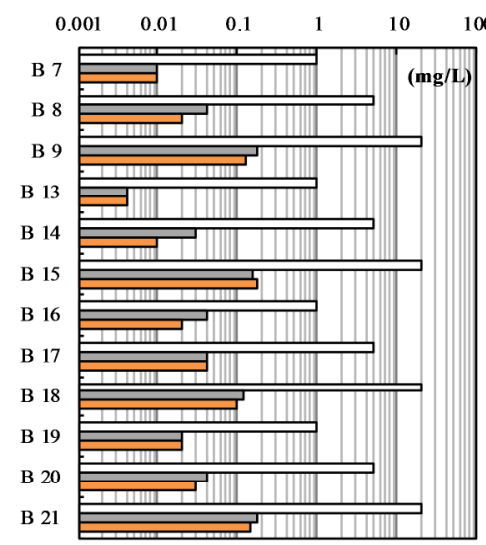

(c) $\mathrm{Pb}$ 濃度

図 8 重金属等吸着試験結果（安定腋 B)

4) 安定液の振とうの 2 日後に, 遠心分離 (3000 rpm, $20 \mathrm{~min}$ ) および $0.45 \mu \mathrm{m}$ メンブレンフィルターでろ過し，得られ たろ液 $\mathrm{a} の \mathrm{As}, \mathrm{F}, \mathrm{Pb}$ 濃度を測定した。検液の作製方法と 濃度測定法を図 5 に示す。なお, 実施工において掘削着 手からコンクリート打設までに 2 日程度を要することが 多いことから，振とう後 2 日の静置期間を設けた。

5) 安定液の理化学特性の評価は粘性, 造壁性および $\mathrm{pH}$ を 測定した。粘性は API 規格のファンネル粘度計を用いて, $500 \mathrm{ml}$ の安定液が流出完了するのに要する時間(s)を計 測した。造壁性は加圧ろ過試験器でろ過試験（ろ過圧 $0.3 \mathrm{MPa}, 30$ 分間, 万紙の保留粒子径 $1 \mu \mathrm{m})$ を行い, 得 られたろ過水量 $(\mathrm{ml})$ を測定した。

\section{3 実験結果と考察}

表 4,5,6 に実験結果を, 図 7,8,9 には重金属等ごとの吸 着試験結果を示す。 $\mathrm{A}, \mathrm{B}, \mathrm{C}$ の各安定液ともに $\mathrm{Pb}$ 濃度の
大幅な低減が確認された。線形軸ではろ液濃度を表示でき ないため, $\mathrm{Pb}$ 濃度のグラフのみ対数軸を用いた。As 濃度 については概ね 25 50\%程度まで低減した。Fについては ほとんじ濃度の低減は見られなかった。また，安定液の性 状（ファンネル粘性, $\mathrm{pH}$, 万過水量）については重金属 混入による有意な変化は見られなかった。実験結果と考察 の詳細について以下に示す。

\section{1) ヒ素}

図 10 に安定液 A, B , C に含まれるべントナイトに対する As（CASE A1 3, B1 3, C1 3） の吸着等温線を示す。吸着 量は初期濃度とろ液 a との差をベントナイト量で除して 求めた。吸着特性を Henry 型として近似直線を描くと, 直 線の傾き（分配係数）は安定液 $\mathrm{A}, \mathrm{B}, \mathrm{C}$ で比較的近い值を 示すことから，ベントナイトによる As 吸着があったと考 えられる。 
表 6 吸着試験結果（安定液 $\mathrm{C}$ : 現場採取安定液）

\begin{tabular}{|c|c|c|c|c|c|c|c|c|c|c|c|c|}
\hline \multirow{3}{*}{ CASE } & \multirow{3}{*}{$\begin{array}{l}\text { 晏 } \\
\text { 液 }\end{array}$} & \multirow{3}{*}{ 重金属 } & \multicolumn{7}{|c|}{ 重金属等の濃度 $(\mathrm{mg} / \mathrm{L})$} & \multicolumn{3}{|c|}{ 安定液の性状 } \\
\hline & & & \multirow{2}{*}{$\begin{array}{c}\text { 初期濃度 } \\
(\mathrm{mg} / \mathrm{L})\end{array}$} & \multicolumn{3}{|c|}{ 万夜 a } & \multicolumn{3}{|c|}{ 万液 b } & \multirow{2}{*}{$\begin{array}{l}\text { 粘性 } \\
\text { (s) }\end{array}$} & \multirow{2}{*}{$\mathrm{pH}$} & \multirow{2}{*}{$\begin{array}{c}\text { 万過水量 } \\
(\mathrm{ml})\end{array}$} \\
\hline & & & & As & $\mathrm{F}$ & $\mathrm{Pb}$ & As & $\mathrm{F}$ & $\mathrm{Pb}$ & & & \\
\hline C 1 & \multirow{21}{*}{ 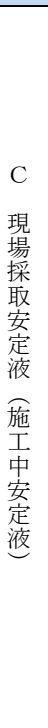 } & \multirow{3}{*}{ As } & 1 & 0.38 & - & - & 0.43 & - & - & 22.7 & 11.7 & 18.2 \\
\hline C 2 & & & 5 & 0.23 & - & - & 1.45 & - & - & 22.8 & 11.8 & 18.2 \\
\hline $\mathrm{C} 3$ & & & 20 & 2.17 & - & - & 3.15 & - & - & 22.6 & 11.8 & 18.2 \\
\hline C 4 & & \multirow{3}{*}{ F } & 1 & - & 1.2 & - & - & 1.4 & - & 22.9 & 11.8 & 14.0 \\
\hline C 5 & & & 5 & - & 4.0 & - & - & 5.0 & - & 22.8 & 11.8 & 14.4 \\
\hline C 6 & & & 20 & - & 14.4 & - & - & 17.1 & - & 22.7 & 11.9 & 14.0 \\
\hline C 7 & & \multirow{3}{*}{$\mathrm{Pb}$} & 1 & - & - & $<0.01$ & - & - & $<0.01$ & 22.7 & 11.8 & 13.6 \\
\hline C 8 & & & 5 & - & - & $<0.01$ & - & - & $<0.01$ & 22.8 & 11.8 & 13.6 \\
\hline C 9 & & & 20 & - & - & 0.08 & - & - & $<0.01$ & 22.9 & 11.7 & 13.2 \\
\hline C 10 & & \multirow{3}{*}{$\mathrm{As}+\mathrm{F}$} & $1+1$ & 0.43 & 1.3 & - & 0.40 & 1.5 & - & 23.0 & 11.6 & 12.0 \\
\hline C 11 & & & $5+5$ & 0.40 & 4.3 & - & 1.41 & 5.1 & - & 22.7 & 11.8 & 12.4 \\
\hline C 12 & & & $20+20$ & 4.27 & 13.8 & - & 3.00 & 16.9 & - & 22.6 & 11.9 & 14.0 \\
\hline C 13 & & \multirow{3}{*}{$\mathrm{F}+\mathrm{Pb}$} & $1+1$ & - & 1.3 & 0.01 & - & 1.6 & $<0.01$ & 22.8 & 11.8 & 12.8 \\
\hline C 14 & & & $5+5$ & - & 4.2 & 0.01 & - & 5.0 & $<0.01$ & 22.7 & 11.8 & 13.2 \\
\hline C 15 & & & $20+20$ & - & 13.7 & 0.07 & - & 15.7 & $<0.01$ & 22.7 & 11.6 & 13.2 \\
\hline C 16 & & \multirow{3}{*}{$\mathrm{As}+\mathrm{Pb}$} & $1+1$ & 0.35 & - & 0.02 & 0.40 & - & $<0.01$ & 23.0 & 11.8 & 12.0 \\
\hline C 17 & & & $5+5$ & 0.78 & - & 0.04 & 1.02 & - & $<0.01$ & 22.8 & 11.8 & 12.0 \\
\hline $\mathrm{C} 18$ & & & $20+20$ & 3.31 & - & 0.10 & 2.51 & - & $<0.01$ & 22.8 & 11.6 & 12.0 \\
\hline C 19 & & \multirow{3}{*}{$\mathrm{As}+\mathrm{F}+\mathrm{Pb}$} & $1+1+1$ & 0.41 & 1.4 & $<0.01$ & 0.40 & 1.9 & $<0.01$ & 23.0 & 11.6 & 11.8 \\
\hline C 20 & & & $5+5+5$ & 1.29 & 4.3 & 0.01 & 1.46 & 5.1 & $<0.01$ & 22.8 & 11.5 & 13.2 \\
\hline C 21 & & & $20+20+20$ & 6.02 & 15.5 & 0.06 & 6.07 & 19.3 & 0.01 & 22.6 & 11.2 & 12.8 \\
\hline
\end{tabular}

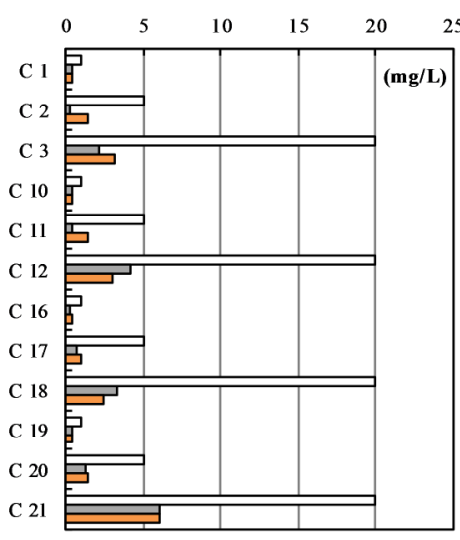

(a) As 濃度

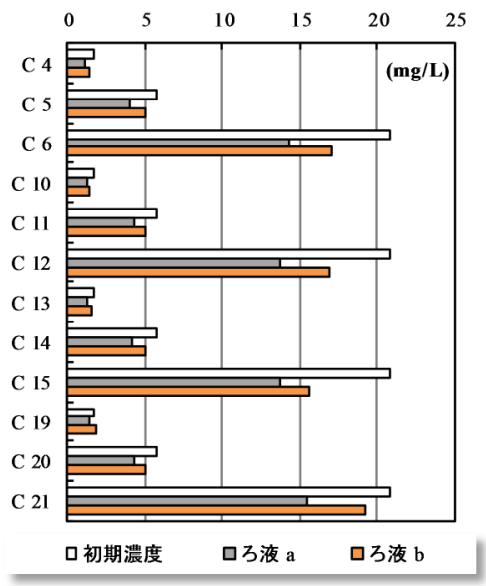

(b) $\mathrm{F}$ 濃度

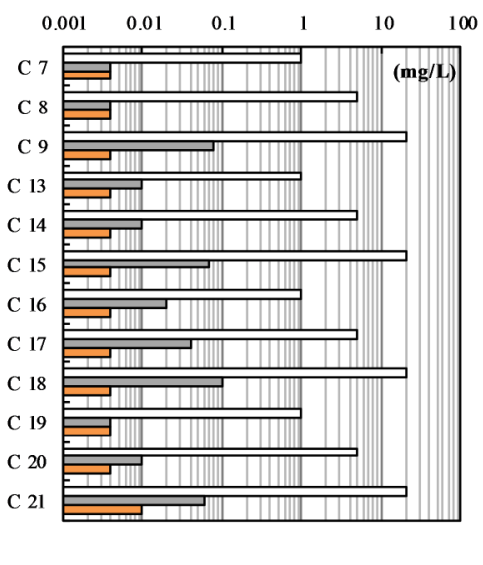

(c) $\mathrm{Pb}$ 濃度

図 9 重金属等吸着試験結果（安定液 C)

ベントナイトによる As 吸着については次のように考え られる。安定液の $\mathrm{pH}$ はおおよそ9１2 の值をとるが，こ のとき $\mathrm{As}$ は亜ヒ酸イオン $\left(\mathrm{H}_{2} \mathrm{AsO}_{3}{ }^{-}\right)$やヒ酸イオン

$\left(\mathrm{HAsO}_{4}{ }^{2-}, \mathrm{AsO}_{4}{ }^{3^{-}}\right)$などの陰イオンの形態で安定液中に存 在する ${ }^{13)}$ 。したがって， ベントナイトの主成分である層 状ケイ酸塩鉱物とのイオン交換や, その結晶端面における イオン吸着反応は起きないはずである。一方で, 表 3 に示 す通り, 実験に用いたベントナイトには随伴鉱物として磁 鉄鉱が含まれているが, 磁鉄鉱は亜ヒ酸を吸着することが 報告されている ${ }^{14)}$ 。本研究の試料においても, 磁鉄鉱に よる亜ヒ酸の吸着が可能性として考えられる。

ろ液 $\mathrm{a}$ の As 濃度はろ液 $\mathrm{b}$ の As 濃度よりも安定液 $\mathrm{A}$ (表 4 CASE A1 3, 10 12, 16 21) で平均約 22\%, 安定液 B (表 5 CASE B1 3, 10 12, 16 21） で平均 3\%, 安定液 C（表 6 CASE C1 3, 10 12, 16 21）で平均 14\%程度低くなった。

この理由は次のように考えられる。前述したような亜ヒ酸

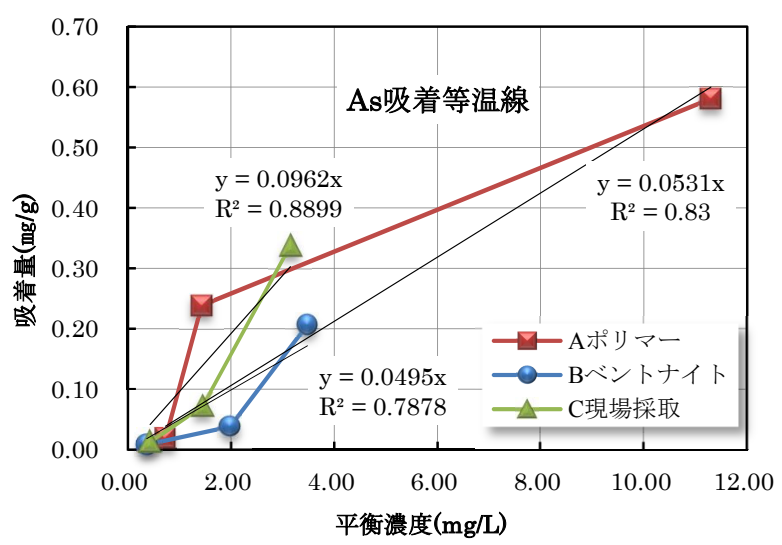

図 10 As 吸着等温線(CASE A1 3, B1 3, C1 3)

イオンと鉄の酸化物, 水酸化物との反応は陽イオン交換反 応のように瞬時には完了しない ${ }^{15)}$ 。振とう直後に行った 加圧ろ過試験器によるろ過によって亜ヒ酸イオンとベン 
トナイトは分離されるが，ろ液 $\mathrm{a}$ の遠心分離・ろ過は約 2 日後に実施したため, その間に亜ヒ酸イオンとベントナイ 卜との吸着反応が進み, 溶出濃度が低下したと考えられる。 また環告 46 号方式によるろ過で用いたメンブレンフィル ター（孔径 $0.45 \mu \mathrm{m} ）$ と, API 規格による加圧ろ過試験で 用いた定性ろ紙（保留粒径 $1 \mu \mathrm{m}$ ）の違いも影響したと考 えられる ${ }^{16)}$

2) フッ素

安定液 $\mathrm{A}, \mathrm{B}, \mathrm{C}$ ともに F 濃度の低減はわずかであった。 これは, Fがアルカリ域において層状ケイ酸塩鉱物や水酸

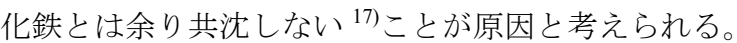

ろ液 $\mathrm{a}$ の $\mathrm{F}$ 濃度はろ液 $\mathrm{b}$ の $\mathrm{F}$ 濃度よりも安定液 $\mathrm{A}$ （表 4 CASE A4 6, 10 15, 19 21）で平均 11\%，安定液 B（表 5 CASE B4 6, 10 15, 19 21） で平均 11\%，安定液 C（表 6 CASE C4 6, 10 15, 19 21) で平均 17\%程度低くなったが, この理由は As と同様, フィルターの種類の違いが原因と 考えられる。

3) 鉛

ろ液 $\mathrm{a}$ の $\mathrm{Pb}$ 濃度は, 安定液 A(表 4 CASE A7 9, 13 21) で<0.01 0.78 mg/L，安定液 B（表 5 CASE B7 9, 13 21） で<0.01 0.18 mg/L, 安定液 C（表 6 CASE C7 9, 13 21） で<0.01 0.10 mg/L となった。安定液 C においては，ろ液 $\mathrm{b}$ の $\mathrm{Pb}$ 濃度は CASE C 21 を除き地下水環境基準 $(0.01 \mathrm{mg} / \mathrm{L})$ 未満と, 顕著な濃度の低下が見られた。安定液の $\mathrm{pH}$ がお およそ 8〜12 とアルカリ性を示していることから，Pb は $\mathrm{Pb}(\mathrm{OH})_{3}$-の陰イオンの形態で安定液中に存在するため, ベ ントナイトの主成分である層状ケイ酸塩鉱物とのイオン 交換や, その結晶端面におけるイオン吸着反応は起きない。 よって，Pb は難溶性の水酸化物の沈殿物を生成したと考 えられる ${ }^{18)}$ 。図 11 に安定液 $\mathrm{A}, \mathrm{B}, \mathrm{C}$ の $\mathrm{pH}$ と $\mathrm{Pb}$ 濃度の関 係を示すが，いずれのケースでも， $\mathrm{pH}$ と $\mathrm{Pb}$ 濃度とは強い 負の相関が見られた。

安定液 B, C では CASE B15 を除いて, ろ液 $\mathrm{b}$ の $\mathrm{Pb}$ 濃度 はろ液 $\mathrm{a}$ の $\mathrm{Pb}$ 濃度よりも低かった。 $\mathrm{Pb}$ のイオン交換反応 や，水酸化物の生成反応の反応時間は $\mathrm{ms}$ （ミリ秒） $\mathrm{min}$

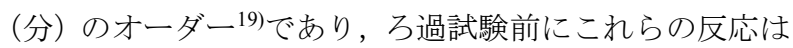
終わり，その後，溶出試験までに新たな吸着反応はおこり 得ない。さらに, 前述したフィルター径の違いにもかかわ らず, ろ液 $\mathrm{a}$ の $\mathrm{Pb}$ 濃度 > ろ液 $\mathrm{b}$ の $\mathrm{Pb}$ 濃度となったのは,

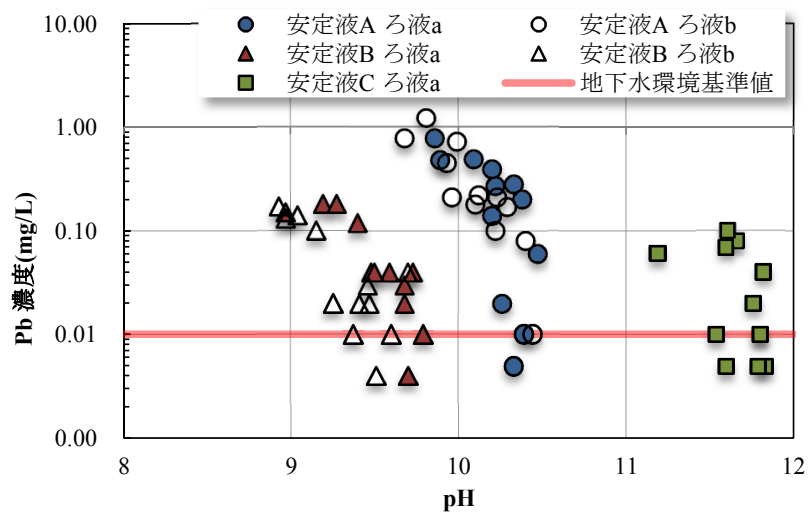

図 $11 \mathrm{~Pb}$ の濃度と $\mathrm{pH}$ の関係
泥膜によるろ過機能が発揮されたと考えられる。つまり， 掘削面を再現した $0.5 \mathrm{MPa}$ の加圧状態において, 土粒子が 密実に充填された泥膜が形成され，それを通過する際に $\mathrm{Pb}$ イオンの多くが吸着，捕捉されたと考えられる。

\section{4) 重金属等の共存による影響について}

他の重金属等との共存による相互作用は，安定液 A, B, $\mathrm{C}$ ともに, $\mathrm{Pb}$ が存在した場合に As の吸着量が抑えられる 傾向が見られた。（図 12）一方で，Pb，Fについては共存 する重金属等による吸着量への影響は見られなかった。

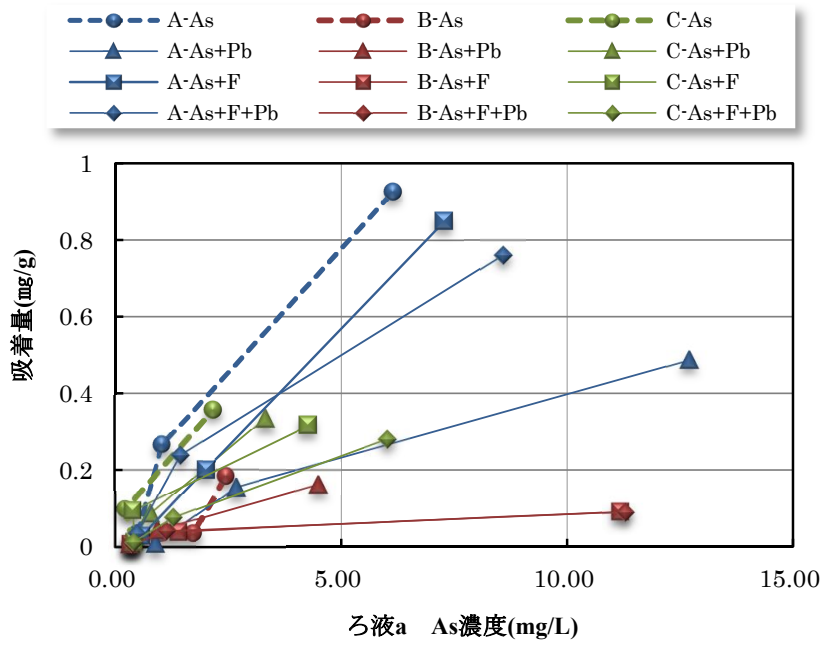

図 12 As 吸着等温線（安定液 A, B, C)

\section{4. 吸着材の適用性の検討}

\section{1 吸着材の性能評価}

3 章では, アースドリル工法で一般に使用されている安 定液懸濁物が, As および $\mathrm{Pb}$ に対して吸着機能をもつこと を明らかにした。特に $\mathrm{Pb}$ に対しては（水酸化物の沈殿も 吸着に含めると）高い吸着機能を有しており，初期濃度が $1 \mathrm{mg} / \mathrm{L}$ 程度であれば地下水環境基準の数倍近くまで濃度 低減が可能であることが明らかとなった。さらに，泥膜の ろ過機能により一定の濃度低下も期待できることがわか つた。

本章では，安定液に添加することによって，As，F の溶 出量を低減するための吸着材を検討する。吸着材は重金属 の不溶化処理に実績のある硫酸第一鉄 $\left(\mathrm{FeSO}_{4}\right)$, 酸化マグ ネシウム $(\mathrm{MgO})$, 炭酸カルシウム $\left(\mathrm{CaCO}_{3}\right)$, ゼオライト, 水酸化アルミニウム $\left(\mathrm{Al}(\mathrm{OH})_{3}\right)$ の 5 種類を選択し吸着性能 の評価を行なった。また，これらの吸着材の添加が安定液 本来の機能（造壁性，粘性，pH）に与える影響について も検証した。

\section{2 実験方法}

重金属等 3 種（As，F，Pb）に対する吸着材の吸着機能 を検証するため, バッチ吸着試験を行った。また, 3.2 と 同様に安定液の理化学特性の評価を行い, 吸着材の添加に よる安定液本来の機能の低下の有無を確認した。実験手順 を以下に示す。 
1）安定液はベントナイト系安定液を使用した。安定液の 作液時の配合を表 7 に示す。

2）安定液を 24 時間養生したのち，吸着材を重量比で $1 \%$ 添加した。吸着材は，硫酸第一鉄（粉末，主成分 $\mathrm{FeSO}_{4}$. $7 \mathrm{H}_{2} \mathrm{O}$ ), 酸化マグネシウム (微粉末, 主成分 $\mathrm{MgO}$ ), 炭酸 カルシウム (微粉末, 主成分 $\mathrm{CaCO}_{3}$ ), ゼオライト (粒状, 主成分 $\mathrm{SiO}_{2}$ ), 非晶質水酸化アルミニウム（粉末, 主成分 $\left.\mathrm{Al}(\mathrm{OH})_{3}\right)$ とした。

3) 対象重金属等は $\mathrm{As}, \mathrm{F}, \mathrm{Pb}$ とし, 原子吸光分析用の 1,000 $\mathrm{mg} / \mathrm{L}$ 標準液をそれぞれ $5 \mathrm{mg} / \mathrm{L}$ の濃度になるよう安定液に 混合し, 1 分間の振とうを行った。

4) 試料は 3.2.5) と同様に安定液の理化学特性の評価を行 ない, 表 1 に示す基準值を満足しない場合には, 分散剤等 で性状の修正を行った。

5) 試料を環告 46 号方式に準拠して遠心分離・ろ過し，ろ 液の $\mathrm{As}, \mathrm{F}, \mathrm{Pb}$ 濃度を測定した。濃度測定法は, As およ び Pb は ICP 質量分析法, F は流れ分析法とした。

\begin{tabular}{l|c}
\multicolumn{2}{c}{ 表 7 ベントナイト安定液の配合 } \\
\hline \multicolumn{1}{c|}{ 安定液成分 } & 配合率 $(\%)$ \\
\hline ベントナイト（浅間\#300） & 8.0 \\
CMC (DKS ポリマー280) & 0.05 \\
分散剂（マーゼル SH） & 0.1 \\
$\mathrm{pH}$ 調整剤（ソーダ灰） & 0.1 \\
\hline
\end{tabular}

\section{3 実験結果と考察}

各重金属等に対する吸着試験結果を図 13 に示す。 硫酸第一鉄は安定液に添加し撹拌したところ著しくゲ ル化した。これは安定液中のベントナイトが鉄イオン

$\left(\mathrm{Fe}^{2+}\right)$ の混入により凝集状態になったためと考えられる。 分散剤等による修正の効果もなかったため, 安定液の混和 材として適用不可と判断した。

ゼオライトは陽イオン交換能が高く ${ }^{20)}, \mathrm{Pb}$ の吸着を期 待したが, 安定液のみのケースと比較して吸着効果は見ら れなかった。

炭酸カルシウムについては $\mathrm{Pb}^{21}$ や $\mathrm{As}^{22)}, \mathrm{F}^{23)}$ の吸着を期 待したが, ゼオライト同様に安定液のみのケースと比較し て吸着効果は見られなかった。

酸化マグネシウムは As, F, Pb すべてをよく吸着し, F と $\mathrm{Pb}$ の濃度が地下水環境基準を満足した。重金属の混入 後にファンネル粘性が $52 \mathrm{~s}$ と表 1 に示す管理基準值を超 過したが, 再振とうすることによって流動性を取り戻した。 なお, 酸化マグネシウムを添加した安定液は他のケースに 比べて $\mathrm{pH}$ が 2 程度上昇した。

水酸化アルミニウムについても, $\mathrm{F}$ と $\mathrm{Pb}$ の濃度が地下 水環境基準を満足した。安定液の性状については, 粘性と ろ過水量がわずかに増加したものの, $\mathrm{pH}$ ともに初期值に 比べて変化がなく良好であった。

以上のことから, 酸化マグネシウムまたは水酸化アルミ ニウムを適切な濃度で安定液に添加することにより, 安定 液本来の機能を損なうことなく, 孔内に混入した As, F
および $\mathrm{Pb}$ の溶出量を基準值未満に低減しうることが示さ れた。

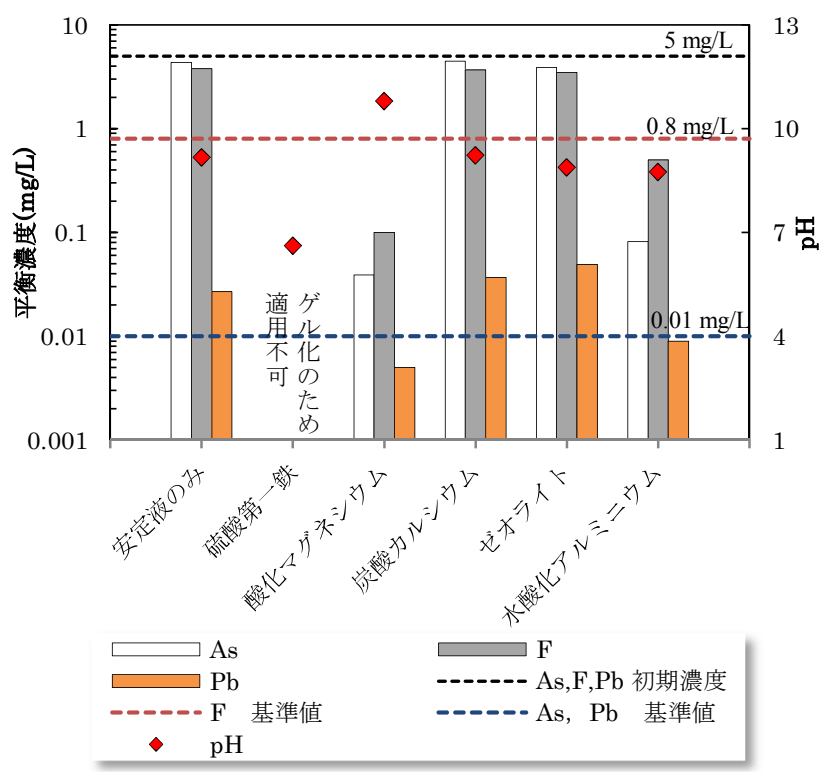

図 13 吸着材の性能試験結果

\section{5. 安定液の配合設計手法の検討}

\section{1 自然由来の重金属等を含む地盤への適用の検討}

4 章では，安定液に吸着材（酸化マグネシウム，水酸化 アルミニウム）を添加することで初期濃度 $5 \mathrm{mg} / \mathrm{L}$ の $\mathrm{Pb}$ および $\mathrm{F}$ の溶出量を地下水環境基準未満に, As について は地下水環境基準の数倍程度 $(0.04 \sim 0.09 \mathrm{mg} / \mathrm{L})$ に濃度低 減できることが示された（図 13）。そこで本章では，自然 由来の重金属污染, すなわち溶出量基準の 10 倍程度 ${ }^{24)}$ 対象として, 安定液に添加する吸着材の効果的な配合につ いて検討する。

\section{2 安定液に溶出する重金属の濃度}

アースドリル工法は安定液の孔内水位を地下水位プラ ス $2 \mathrm{~m}$ 以上に保ちながら掘削を行うため, 孔内から周辺地 盤への移流によって, 掘削壁面から孔内への拡散はその大 部分が抑えられると考えられる。したがって, 本研究では, 安定液には, 掘削土壌から溶出した重金属等のみ混入する と考える。以下に, 掘削土壤から安定液への重金属の混入 について考察する。

図 14 にアースドリル工法による掘削手順を示す。まず, 表層ケーシングの建込み予定深度 (3 m 程度) まで掘削し

(図 14-a), 表層ケーシングを立て込んだ後, 安定液を注 入する（図 14-b）。その後は，安定液の液面を一定に保ち ながらドリリングバケツで掘削し地上へ排土，という作業 を繰り返す (図 14-c)。したがって，表層ケーシング以深 の土壤は, 掘削および地上への排土工程において安定液と 接触し, その体積比は杭長にもよるが，概ね $1: 1$ と考え られる。 


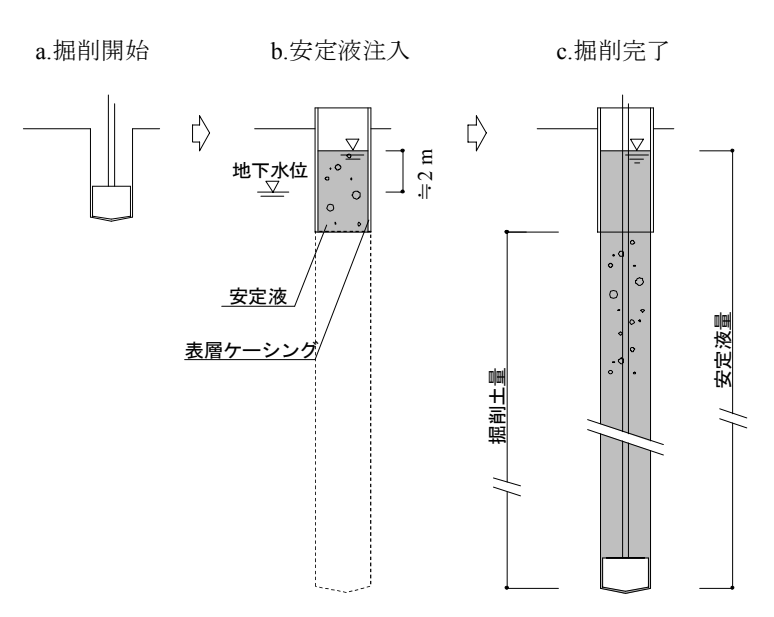

掘削土体積 $\fallingdotseq$ 安定液体積

図 14 掘削土と安定液の体積比

図 15 に污染土壌と安定液の構成を示すが, 体積比を $1: 1$ と想定すると，

$$
V_{\mathrm{s}}+V_{\mathrm{w}}=V_{\mathrm{s} 1}
$$

であるから, 土粒子の乾燥質量 $m_{\mathrm{s}}$ と間隙水の質量 $m_{\mathrm{w}}$ およ び安定液中の水の質量 $m_{\mathrm{wsl}}$ は以下のように示すことがで きる。

$$
\begin{aligned}
& m_{\mathrm{s}}=\rho_{\mathrm{s}} \cdot V_{\mathrm{s}} \\
& m_{\mathrm{w}}=\rho_{\mathrm{w}} \cdot V_{\mathrm{w}}=\rho_{\mathrm{w}} \cdot e V_{\mathrm{s}} \\
& m_{\mathrm{wsl}}=\rho_{\mathrm{sl}} \cdot V_{\mathrm{sl}}(1-\alpha)=\rho_{\mathrm{sl}} \cdot V_{\mathrm{s}}(1+e)(1-\alpha)
\end{aligned}
$$

ここで $n$ を, 間隙水と安定液中の水分との質量和 $\left(m_{\mathrm{w}}+\right.$ $\left.m_{\mathrm{ws} l}\right)$ と土粒子の質量 $m_{\mathrm{s}}$ との比と定義すると,

$$
n=\left(m_{\mathrm{w}}+m_{\mathrm{ws}}\right) / m_{\mathrm{s}}=\left\{\rho_{\mathrm{w}} \cdot e+\rho_{\mathrm{sl}} \cdot(1+e)(1-\alpha)\right\} / \rho_{\mathrm{s}}
$$

となる。ここで,

$V_{\mathrm{sl}}$ : 安定液の体積, $V_{\mathrm{s}}$ : 固相の体積, $V_{\mathrm{w}}$ : 液相の体積 $m_{\mathrm{w}}$ : 間隙水の質量, $m_{\mathrm{s}}$ : 土粒子の乾燥質量

$m_{\mathrm{wsl}}$ : 安定液に含まれる水の質量,

$m_{\mathrm{b}}$ : ベントナイト等の乾燥質量, $m_{\mathrm{sl}}$ : 安定液の質量,

$\alpha$ : ベントナイト等の配合率 $=m_{\mathrm{b}} / m_{\mathrm{s}}$,

$\rho_{\mathrm{s}}$ : 土粒子の密度, $\rho_{\mathrm{s} 1}$ : 安定液の密度,

$\rho_{\mathrm{w}}:$ 水の密度, $e:$ 間隙比 $=V_{\mathrm{w}} / V_{\mathrm{s}}$

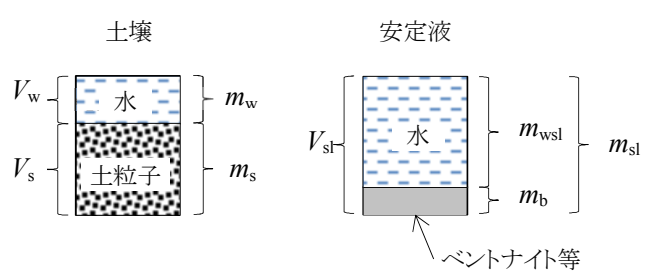

図 15 掘削土壤と安定液の構成
この污染土猿の溶出量值（環境庁告示第 46 号方式に準 拠し液固比 10 で測定）を $c_{0}(\mathrm{mg} / \mathrm{L})$ とし，安全側の仮定と して，土壌からの重金属の溶出量が一定であるとすれば, 安定液の液相濃度 $c$ は次式を満足する。なお地下水污染は ないものとする。

$$
\begin{aligned}
& 10 \cdot c_{0}=n \cdot c \\
& c=10 c_{0} \cdot \rho_{\mathrm{s}} /\left\{\rho_{\mathrm{w}} \cdot e+\rho_{\mathrm{sl}} \cdot(1+e)(1-\alpha)\right\}
\end{aligned}
$$

たとえば, $c_{0}=0.10 \mathrm{mg} / \mathrm{L}, e=1.0, \rho_{\mathrm{s}}=2.65 \mathrm{t} / \mathrm{m}^{3}$ の重金属 による污染土層を $\rho_{\mathrm{sl}}=1.05 \mathrm{t} / \mathrm{m}^{3}$ の安定液を用いて掘削 した場合, 掘削完了時の安定液の液相濃度は, 最大で $c=$ $0.89 \mathrm{mg} / \mathrm{L}$ となる。これは元の土壌の溶出量值 $c_{0}$ の概ね 10 倍程度である。

\section{3 実験方法}

表 8 にバッチ吸着試験の実験条件を示す。対象重金属は As, F, $\mathrm{Pb}$ の 3 種類に, 3 種混合溶液を含めた 4 種類とし た。各重金属の濃度は，それぞれ土䁃溶出量基準の 100 倍とした。これは, 自然由来の重金属等污染土壌の溶出量 值が概ね土袞溶出量基準の 10 倍以内であり ${ }^{24)}$, この土壌 を含む地盤をアースドリル工法で掘削すると, 前節で述べ たように安定液の液相濃度が, 最大で土畩溶出量基準の 100 倍程度になると想定している。

吸着材は 4 章の実験結果から, 酸化マグネシウム $(\mathrm{MgO})$ と水酸化アルミニウム $\left(\mathrm{Al}(\mathrm{OH})_{3}\right)$ の 2 種類とした。添加量 は対象重金属等が $\mathrm{As}, \mathrm{Pb}$ 単独の場合は $0.5,1.0,2.0 \%$ の 3 水準とし, $\mathrm{F}$ を含むケースについては 1.0, 2.0, 5.0\%の 3 水 準とした。安定液の種類は, 表 2 に示す A ポリマー系安 定液および $\mathrm{B}$ ベントナイト系安定液の 2 種類とした。な お，本章の実験では安定液 $\mathrm{A}, \mathrm{B}$ ともに粘土分を加えてい ない。

実験手順は，まず，安定液を作液後 24 時間養生したの ち, 吸着材を所定量添加した。その後, 原子吸光分析用の $1000 \mathrm{~mL}$ 標準液を所定の濃度になるように混合し 1 分間の 手振とうを行った。振とうの 2 日後に環告 46 号に準じて 遠心分離 - 万過し, 万液の As, F, Pb 濃度を測定した。 また, 吸着材や重金属等の混入による安定液の機能の低下 の有無を確認するため, 表 1 に示す安定液の理化学特性の 評価も実施した。なお, 濃度測定法は, As および Pb は ICP 質量分析法，Fは流れ分析法とした。

\section{4 実験結果とその考察}

\section{1) 安定液の理化学特性の評価}

表 8 に示す CASE A-1〜24 および CASE B-1〜24 に対 寸る安定液の理化学特性の評価（ファンネル粘性，ろ過 水量, $\mathrm{pH}$ ) の結果を図 16 に示す。以下に管理項目ごと の実験結果と考察を述べる。

\section{a) 粘性(ファンネル粘性)}

安定液 $\mathrm{A}$ に $\mathrm{MgO}$ および $\mathrm{Al}(\mathrm{OH})_{3}$ を添加することによる ファンネル粘性の変化は安定しており，全ケースで 30 秒 
表 8 バッチ吸着試験・安定液品質管理試験の試験条件および試験結果

\begin{tabular}{|c|c|c|c|c|c|c|c|c|c|c|c|c|c|c|c|}
\hline \multirow{3}{*}{ CASE } & \multirow{3}{*}{$\begin{array}{l}\text { 安定 } \\
\text { 液 }\end{array}$} & \multicolumn{2}{|c|}{ 吸着材 } & \multicolumn{2}{|c|}{ 重金属等 } & \multicolumn{5}{|c|}{ 安定液の液相濃度 } & \multicolumn{5}{|c|}{ 安定液の性状 } \\
\hline & & \multirow{2}{*}{ 名称 } & \multirow{2}{*}{$\begin{array}{l}\text { 添加量 } \\
\text { (\%) }\end{array}$} & \multirow{2}{*}{ 名称 } & \multirow{2}{*}{$\begin{array}{l}\text { 濃度 } \\
(\mathrm{ppm})\end{array}$} & \multicolumn{3}{|c|}{ 平衡濃度(ppm) } & \multirow{2}{*}{$\mathrm{pH}$} & \multirow{2}{*}{$\begin{array}{l}\text { 温度 } \\
\left({ }^{\circ} \mathrm{C}\right)\end{array}$} & \multirow{2}{*}{$\begin{array}{l}\text { 粘性 } \\
\text { (s) } \\
22 \sim 40\end{array}$} & \multirow{2}{*}{$\begin{array}{c}\mathrm{pH} \\
7.0 \sim 10.5\end{array}$} & \multirow{2}{*}{$\begin{array}{c}\text { 万過水量 } \\
(\mathrm{ml}) \\
\leqq 20 \\
\end{array}$} & & 備考 \\
\hline & & & & & & As & $\mathrm{F}$ & $\mathrm{Pb}$ & & & & & & & \\
\hline A-1 & & & 0.5 & & & 0.007 & & & 11.5 & 24.1 & 31.3 & 10.5 & 6.2 & & \\
\hline $\mathrm{A}-2$ & & & 1.0 & As & 1 & $<0.005$ & & & 11.8 & 24.4 & 31.0 & 10.6 & 6.8 & & \\
\hline $\mathrm{A}-3$ & & & 2.0 & & & $<0.005$ & & & 11.9 & 25.0 & 30.2 & 10.7 & 8.0 & & \\
\hline A-4 & & 酸 & 1.0 & & & & 1.1 & & 11.9 & 24.4 & 29.0 & 10.6 & 7.0 & & \\
\hline A-5 & & 化 & 2.0 & F & 80 & & 0.7 & & 12.0 & 23.8 & 28.2 & 10.6 & 8.0 & & \\
\hline A-6 & & グ & 5.0 & & & & 0.4 & & 12.1 & 23.8 & 28.0 & 10.7 & 9.2 & & \\
\hline A-7 & & ネ & 0.5 & & & & & $<0.005$ & 11.8 & 23.1 & 29.7 & 10.6 & 7.0 & & \\
\hline A-8 & & ウ & 1.0 & $\mathrm{~Pb}$ & 1 & & & $<0.005$ & 11.9 & 22.8 & 29.3 & 10.7 & 8.0 & & \\
\hline A-9 & A & 厶 & 2.0 & & & & & $<0.005$ & 12.0 & 22.7 & 29.0 & 10.7 & 8.4 & & \\
\hline A-10 & & & 1.0 & & & $<0.005$ & 1.2 & $<0.005$ & 12.0 & 22.3 & 28.5 & 10.6 & 8.0 & & \\
\hline A-11 & 木 & & 2.0 & $\mathrm{As}+\mathrm{F}+\mathrm{Pb}$ & $1+80+1$ & $<0.005$ & 0.9 & $<0.005$ & 12.0 & 24.5 & 28.1 & 10.7 & 9.0 & & \\
\hline $\mathrm{A}-12$ & ₹ & & 5.0 & & & $<0.005$ & 0.5 & $<0.005$ & 12.2 & 23.9 & 28.0 & 10.8 & 9.2 & 6h後 米 & 粘性27.6s \\
\hline A-13 & 1 & & 0.5 & & & 0.041 & & & 9.1 & 23.9 & 28.9 & 9.2 & 8.0 & & \\
\hline A-14 & 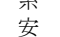 & & 1.0 & As & 1 & 0.016 & & & 8.8 & 23.3 & 28.7 & 9.0 & 8.4 & & \\
\hline $\mathrm{A}-15$ & 定 & & 2.0 & & & 0.015 & & & 8.5 & 23.8 & 28.6 & 8.5 & 9.0 & & \\
\hline A-16 & 液 & $\begin{array}{l}\text { 水 } \\
\text { 酸 }\end{array}$ & 1.0 & & & & 16.5 & & 9.0 & 23.3 & 28.0 & 9.1 & 9.0 & & \\
\hline A-17 & & 化 & 2.0 & F & 80 & & 3.8 & & 8.6 & 23.3 & 27.9 & 8.8 & 9.2 & & \\
\hline A-18 & & 了 & 5.0 & & & & 0.5 & & 8.3 & 22.7 & 27.3 & 8.1 & 11.0 & & \\
\hline A-19 & & ミ & 0.5 & & & & & 0.018 & 9.1 & 23.5 & 29.1 & 9.3 & 9.0 & & \\
\hline A-20 & & $=$ & 1.0 & $\mathrm{~Pb}$ & 1 & & & 0.012 & 8.8 & 23.4 & 29.0 & 9.0 & 9.6 & & \\
\hline $\mathrm{A}-21$ & & a & 2.0 & & & & & 0.009 & 8.5 & 23.2 & 28.9 & 8.6 & 10.4 & & \\
\hline A-22 & & & 1.0 & & & 0.029 & 19.2 & 0.013 & 9.0 & 23.3 & 28.0 & 9.1 & 10.0 & & \\
\hline $\mathrm{A}-23$ & & & 2.0 & $\mathrm{As}+\mathrm{F}+\mathrm{Pb}$ & $1+80+1$ & 0.010 & 4.2 & 0.008 & 8.6 & 23.2 & 27.7 & 8.8 & 10.2 & & \\
\hline $\mathrm{A}-24$ & & & 5.0 & & & $<0.005$ & 0.5 & $<0.005$ & 8.3 & 23.4 & 27.6 & 8.2 & 10.8 & 6h後 米 & 粘性 $27.2 \mathrm{~s}$ \\
\hline B-1 & & & 0.5 & & & 0.030 & & & 10.8 & 24.6 & 28.6 & 10.7 & 7.6 & & \\
\hline B-2 & & & 1.0 & As & 1 & 0.014 & & & 11.1 & 24.4 & 29.4 & 10.7 & 7.6 & & \\
\hline B-3 & & & 2.0 & & & 0.010 & & & 11.1 & 24.1 & 30.8 & 10.9 & 9.7 & & \\
\hline B-4 & & 酸 & 1.0 & & & & 1.8 & & 10.9 & 23.6 & 27.1 & 10.7 & 7.2 & & \\
\hline B-5 & & 华 & 2.0 & F & 80 & & 0.6 & & 11.4 & 23.5 & 27.8 & 10.7 & 7.6 & & \\
\hline B-6 & & グ & 5.0 & & & & & & & & & & & & \\
\hline B-7 & & ネ & 0.5 & & & & & $<0.005$ & 10.8 & 24.6 & 27.9 & 10.8 & 7.4 & & \\
\hline B-8 & $B$ & ウ & 1.0 & $\mathrm{~Pb}$ & 1 & & & $<0.005$ & 11.5 & 24.1 & 27.4 & 10.9 & 8.0 & & \\
\hline B-9 & $D$ & 厶 & 2.0 & & & & & $<0.005$ & 11.9 & 24.4 & 29.7 & 10.9 & 9.2 & & \\
\hline B-10 & ベ & & 1.0 & & & 0.049 & 8.8 & $<0.005$ & 10.7 & 24.1 & 28.5 & 10.7 & 7.8 & & \\
\hline B-11 & , & & 2.0 & $\mathrm{As}+\mathrm{F}+\mathrm{Pb}$ & $1+80+1$ & $<0.005$ & 1.4 & $<0.005$ & 11.8 & 24.4 & 48.0 & 10.8 & 8.1 & 6h後 & ゲル化 \\
\hline B-12 & ナ & & 5.0 & & & & & & & & & & & & \\
\hline B-13 & 1 & & 0.5 & & & 0.147 & & & 8.9 & 24.3 & 30.1 & 9.1 & 7.6 & & \\
\hline B-14 & 系 & & 1.0 & As & 1 & 0.036 & & & 8.7 & 24.7 & 30.2 & 9.6 & 7.7 & & \\
\hline B-15 & 安 & & 2.0 & & & 0.014 & & & 8.5 & 24.8 & 32.0 & 8.9 & 7.1 & & \\
\hline B-16 & 定 & 酸 & 1.0 & & & & 15.9 & & 8.9 & 24.2 & 27.7 & 9.4 & 7.6 & & \\
\hline B-17 & & 化 & 2.0 & F & 80 & & 6.6 & & 8.6 & 24.5 & 27.6 & 9.2 & 7.9 & & \\
\hline B-18 & & P & 5.0 & & & & 1.0 & & 8.3 & 24.5 & 28.2 & 8.9 & 7.9 & & \\
\hline B-19 & & ミ & 0.5 & & & & & 0.013 & 8.8 & 24.0 & 27.9 & 9.3 & 7.4 & & \\
\hline $\mathrm{B}-20$ & & $=$ & 1.0 & $\mathrm{~Pb}$ & 1 & & & 0.008 & 8.7 & 24.0 & 27.1 & 9.1 & 7.8 & & \\
\hline B-21 & & म & 2.0 & & & & & $<0.005$ & 8.5 & 24.4 & 30.7 & 8.7 & 8.6 & & \\
\hline B-22 & & & 1.0 & & & 0.031 & 9.4 & 0.016 & 8.8 & 24.9 & 27.6 & 9.1 & 7.7 & & \\
\hline B-23 & & & 2.0 & $\mathrm{As}+\mathrm{F}+\mathrm{Pb}$ & $1+80+1$ & 0.011 & 6.1 & $<0.005$ & 8.6 & 24.7 & 27.8 & 9.3 & 9.2 & & \\
\hline B-24 & & & 5.0 & & & $<0.005$ & 1.0 & $<0.005$ & 8.3 & 24.5 & 45.0 & 8.5 & 9.8 & 6h後 & ゲル化 \\
\hline
\end{tabular}

前後を推移した。一方で，安定液 B は CASE B-11（添加 量 2\%) でファンネル粘性が 48 秒と管理基準值を超過した ためCASE B-6, B-12（添加量 5\%）の試験は取りやめた。 また, CASE B-24（添加量 5\%）のファンネル粘性も 45 秒 と管理基準值を超過した。なお, CASE B-11 およびCASE B-24の安定液は試験後 6 時閒静置したところ一旦ゲル化 したが，振動を与えることによって流動性は戻った。

安定液 B で, 吸着材の添加量の増加に伴って粘性とろ 過水量が増大したのは, 吸着材に含まれる金属イオン

$\left(\mathrm{Mg}^{2+}\right.$ や $\left.\mathrm{Al}^{3+}\right)$ の混入により安定液が凝集状態になったた めと考えられる。ファンネル粘性が管理基準值を超過した
ことから安定液 $\mathrm{B}$ ，才なわちベントナイト系安定液への $\mathrm{MgO}$ の添加量は $2 \%$ 未満, $\mathrm{Al}(\mathrm{OH})_{3}$ の添加量は $5 \%$ 未満と すべきであろう。一方で，ポリマー系安定液はベントナイ 卜系安定液に比べて金属イオンに対する而凝集性を有し ており ${ }^{25)}$, 吸着材の添加量の増加に伴い粘性とろ過水量 が増加するものの，管理基準值を超過することはなかった。

\section{b) 造壁性}

造壁性はろ過水量を測定することで把握できる。 $\mathrm{MgO}$, $\mathrm{Al}(\mathrm{OH})_{3}$ ともに添加量が増えると, 万過水量が増加する傾 向が見られた。このことから, $\mathrm{MgO}, \mathrm{Al}(\mathrm{OH})_{3}$ ともに添加 量が少ないほど造壁性が良いと言える。しかしながら， 

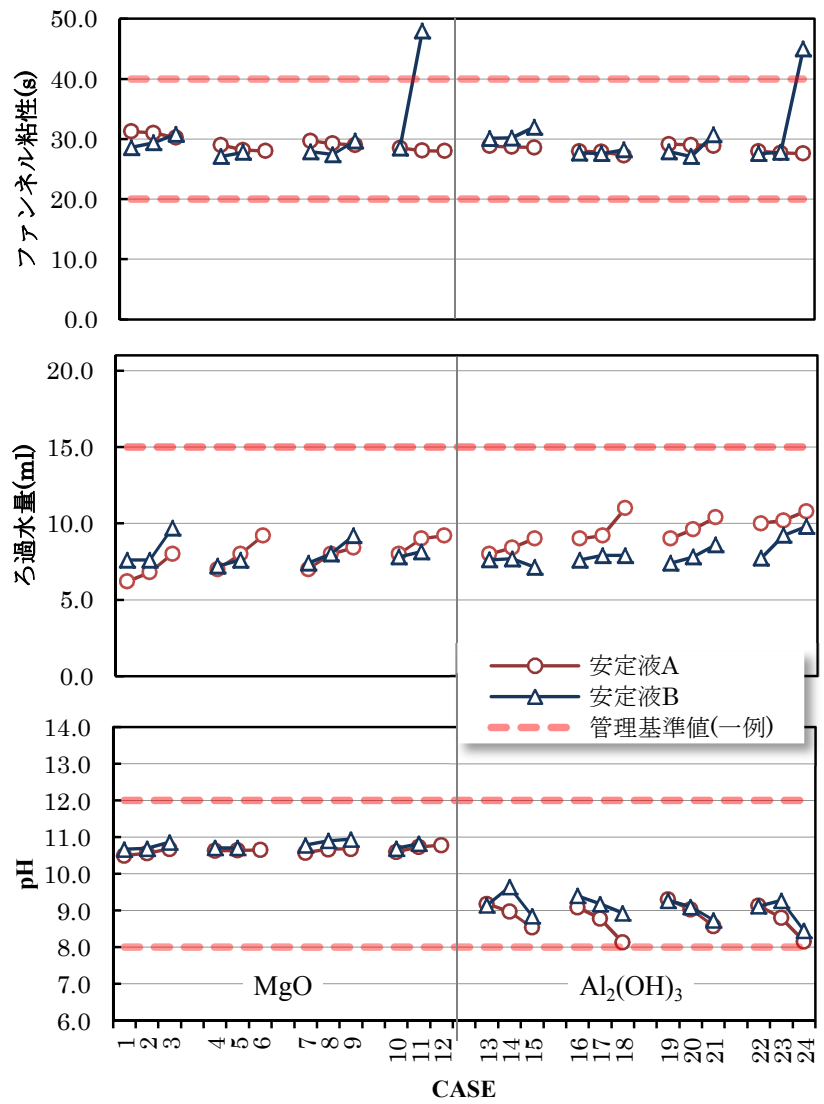

図16 安定液の理化学特性の評価

$\mathrm{MgO}$ を 0.5 5\%添加した場合, 万過水量は 6 10 ml に分布 し, $\mathrm{Al}(\mathrm{OH})_{3}$ を 0.5 5\%添加した場合には, 万過水量は 7 11 $\mathrm{ml}$ に分布した。いずれも表 1 に示す管理基準值内の值で あり, 本実験条件においては吸着剤の添加による造壁性へ の影響は小さいと言える。ただし安定液 $\mathrm{A}$ に $\mathrm{Al}(\mathrm{OH})_{3}$ を 5\%添加した CASE A-18 で急激なろ過水量の増加が見られ たことから，安定液 A，すなわちポリマー系安定液に対す る $\mathrm{Al}(\mathrm{OH})_{3}$ の添加量は $5 \%$ 程度を上限とすべきと考えられ る。

c) $\mathrm{pH}$

安定液 $\mathrm{A}, \mathrm{B}$ とも, $\mathrm{MgO}$ の添加による $\mathrm{pH}$ の変化は小さ く, pH10 11 の間に分布した。一方で, $\mathrm{Al}(\mathrm{OH})_{3}$ の添加に よる $\mathrm{pH}$ の変化は比較的大きく, 特に, 安定液 $\mathrm{A}$ に $\mathrm{Al}(\mathrm{OH})_{3}$ を 5\%添加した場合に $\mathrm{pH}$ は 8 と管理基準值の下限近くに なった。

\section{2) 吸着材の添加量と平衡濃度}

図 17 に吸着材 $\mathrm{MgO}$ および $\mathrm{Al}(\mathrm{OH})_{3}$ の添加量と安定液 $\mathrm{A}$ の各重金属濃度との関係を示す。As については F, Pb と の混合による影響は少なく, $\mathrm{MgO}$ の添加量は $0.5 \%$ 以上に することで As 濃度を地下水環境基準未満に抑えることが できる。 $\mathrm{Al}(\mathrm{OH})_{3}$ の添加量は $5 \%$ 以上にすることで As 濃度 を地下水環境基準未満に抑えることができる。 Fについて は $\mathrm{MgO}$ を添加した場合に $\mathrm{As}, \mathrm{Pb}$ との共存による影響が 見られ, $\mathrm{MgO}, \mathrm{Al}(\mathrm{OH})_{3}$ の添加量はそれぞれ 5\%以上にす ることで $\mathrm{F}$ 濃度を地下水環境基準未満に抑えることがで
きる。 $\mathrm{Pb}$ については, $\mathrm{MgO}$ を添加した場合, 全ケースで 地下水環境基準未満になった。 $\mathrm{Al}(\mathrm{OH})_{3}$ を添加した場合, As, F との共存による影響は少なく, 添加量を $2 \%$ 以上に することで $\mathrm{Pb}$ 濃度を地下水環境基準未満に抑えることが できる。

図 18 に吸着材 $\mathrm{MgO}$ および $\mathrm{Al}(\mathrm{OH})_{3}$ の添加量と安定液 B の各重金属濃度との関係を示す。Asについては F, Pb と の混合による影響は少なく, $\mathrm{MgO}, \mathrm{Al}(\mathrm{OH})_{3}$ の添加量はそ れぞれ $2 \% ， 5 \%$ 以上にすることで，As 濃度を地下水環境 基準未満に抑えることができる。 Fについては $\mathrm{MgO}$ を添 加した場合に $\mathrm{As}, \mathrm{Pb}$ との共存による影響が見られ， $\mathrm{F}$ 単 体の場合のみ添加量を $2 \%$ 以上にすることで地下水環境基 準未満に抑えることができた。 $\mathrm{F} に \mathrm{Al}(\mathrm{OH})_{3}$ を添加した場 合, $\mathrm{As}, \mathrm{Pb}$ との共存による影響は見られず, 添加量 5\%以 下で $\mathrm{F}$ 濃度は地下水環境基準を満足しなかった。 $\mathrm{Pb}$ に $\mathrm{MgO}$ を添加した場合, 全ケースで地下水環境基準未満に なった。 $\mathrm{Pb}$ に $\mathrm{Al}(\mathrm{OH})_{3}$ を添加した場合， $\mathrm{As} ， \mathrm{~F}$ との共存に よる影響が見られ, 添加量を $2 \%$ 以上にすることで地下水 環境基準を満足した。

\section{3) 安定液と吸着材の最適な組合せ}

図 19，20 にそれぞれ As，F の吸着等温線を示す。As, $\mathrm{F}$ ともに $\mathrm{Al}(\mathrm{OH})_{3}$ よりも $\mathrm{MgO}$ の吸着機能が高い。中でも 安定液 $\mathrm{A}$ に $\mathrm{MgO}$ を添加したケースが最も吸着機能が高い。 なお, $\mathrm{Pb}$ に対しても， $\mathrm{Al}(\mathrm{OH})_{3}$ よりも $\mathrm{MgO}$ を添加したほ うが吸着量は大きいことがわかった。

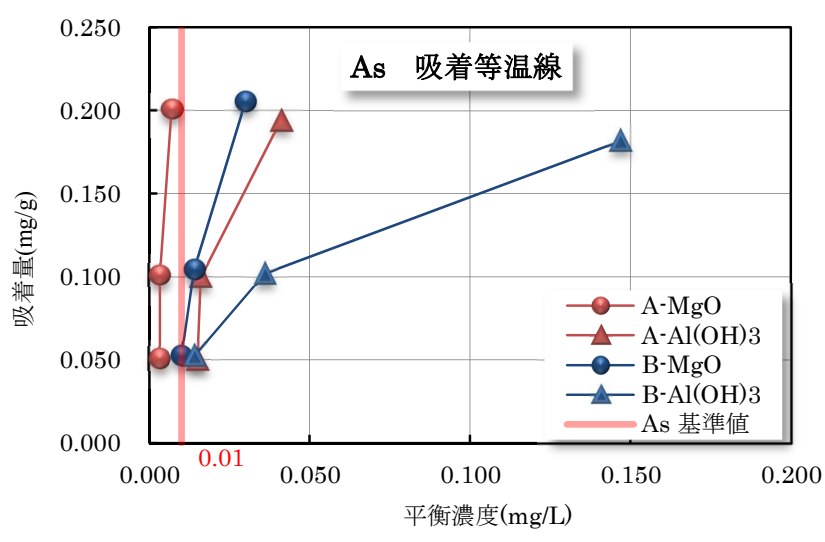

図 19 As 吸着等温線

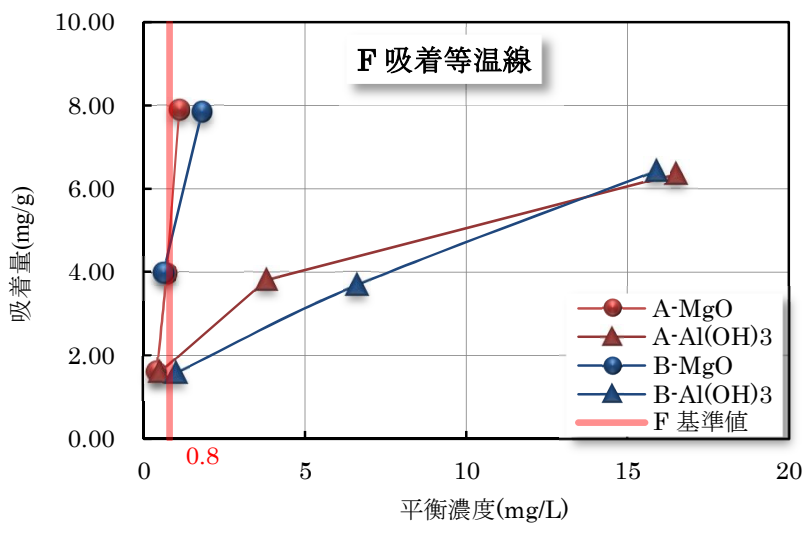

図 $20 \mathrm{~F}$ 吸着等温線 

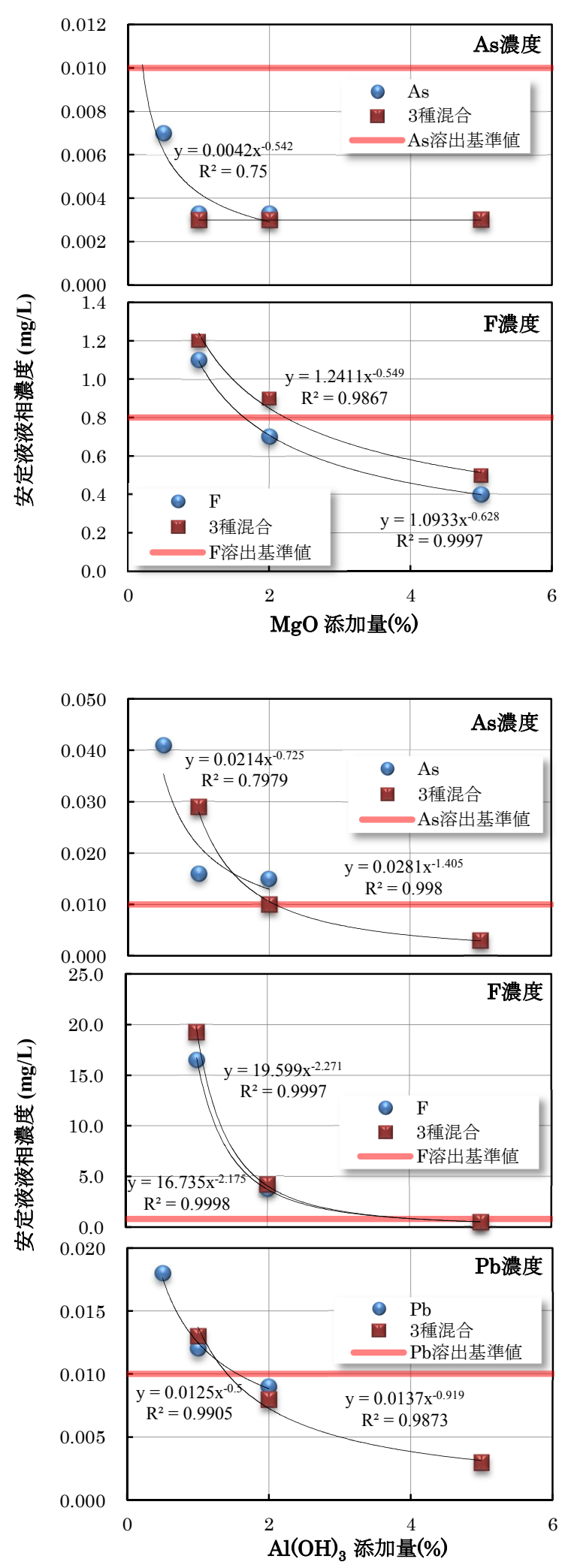

図 17 吸着材添加量と重金属濃度【安定液 $\mathrm{A}$ 】

\section{4) 考察}

a) 水酸化アルミニウムによる重金属の吸着について

$\mathrm{Al}(\mathrm{OH})_{3}$ は活性な表面水酸基を有しており図 21 に示す 水酸化鉄と同様に, 陽イオンである $\mathrm{Pb}^{2+}$ や陰イオンである $\mathrm{F}^{-}$や $\mathrm{H}_{2} \mathrm{AsO}_{3}{ }^{-}$，も吸着し表面錯体を形成する ${ }^{26)}$ 。ここで, $\mathrm{Al}(\mathrm{OH})_{3}$ を添加した場合の安定液の $\mathrm{pH}$ は 8.1〜9.6を示し
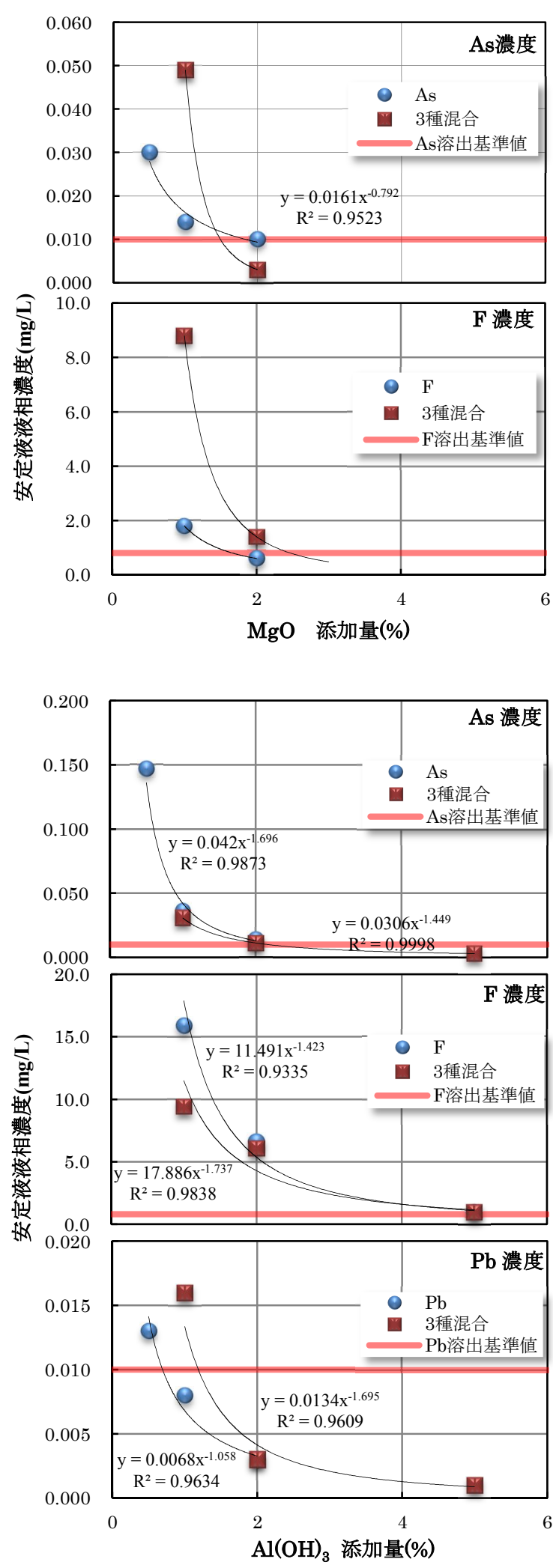

図 18 吸着材添加量と重金属濃度【安定液 B】

ており，これは CASE B-14 を除き $\mathrm{Al}(\mathrm{OH})_{3}$ の電位ゼロ点 である 9.5 27)より小さい。このため, $\mathrm{Al}(\mathrm{OH})_{3}$ は正電荷を有 し, $\mathrm{F}^{-}$や $\mathrm{H}_{2} \mathrm{AsO}_{3}{ }^{-}$を吸着したと考えられる。CASE A-19〜 21 および CASE B-19〜21 における $\mathrm{Pb}$ 濃度と, 3 章の実験 結果（表 4 の A-7 および B-7）と比較して, $\mathrm{Al}(\mathrm{OH})_{3}$ によ 
る $\mathrm{Pb}$ の濃度低減効果が見られないことからも, $\mathrm{Pb}$ が難溶 性の水酸化物を生成したことが示唆される。

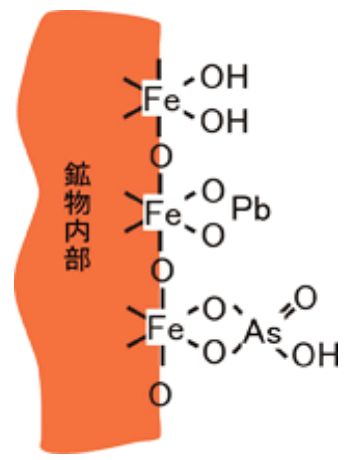

図 21 水酸化鉄鉱物表面一の結合の模式図 ${ }^{24)}$

ポリマー系安定液を夏場に使用する場合, バクテリアに

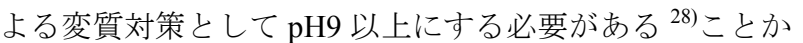
ら, $\mathrm{Al}(\mathrm{OH})_{3}$ を添加する際には添加量を制限するか，アル カリ剤の使用を検討する必要がある。しかし前述したとお り, $\mathrm{Al}(\mathrm{OH})_{3}$ の電位ゼロ点は 9.5 であり, $\mathrm{pH}$ を 9 以上にす ることによって As および F の吸着効果が低下寸る可能性 があるため, 実施工への適用の際には注意を要する。

b) 酸化マグネシウムによる重金属の吸着について

$\mathrm{MgO}$ を添加した場合の $\mathrm{pH}$ は 10.5〜11 を示しており， この值は $\mathrm{MgO}$ の電位ゼロ点である $12.4^{14)}$ よりも低い。こ のため $\mathrm{MgO}$ も正電荷を有しており $\mathrm{F}^{-}$や $\mathrm{H}_{2} \mathrm{AsO}_{3}{ }^{-}$を吸着し 表面錯体を形成すると考えられる。また $\mathrm{MgO}$ が水と反応 して $\mathrm{Mg}(\mathrm{OH})_{2}$ に変化する際に $\mathrm{F}$ が取り込まれるとも考え られている。 $\mathrm{Pb}$ について $\mathrm{MgO}$ による不溶化の機構が明 らかになっていないが， $\mathrm{pH}$ 上昇による水酸化鉛の生成な どが考えられている ${ }^{29) 。 ~}$

CASE A-1〜12 では，実験時（MgO の添加直後）から濃 度分析時（2 日後）までに, $\mathrm{pH}$ が 1 程度上昇した。この 理由は次のように考える。式(7)に示すように, $\mathrm{MgO}$ は水 溶液中で溶解し水酸化物イオンを供給するため $\mathrm{pH}$ が上昇 するが，その後式(8)に示すように過飽和状態になったマ グネシウムイオンと水酸化物イオンが水酸化マグネシウ ムイオンとして沈殿する ${ }^{30)}$ 。

$$
\begin{aligned}
& \mathrm{MgO}+\mathrm{H}_{2} \mathrm{O} \Leftrightarrow \mathrm{Mg}^{2+}+2 \mathrm{OH}^{-} \\
& \mathrm{Mg}^{2+}+2 \mathrm{OH}^{-} \Leftrightarrow \mathrm{Mg}(\mathrm{OH})_{2}
\end{aligned}
$$

しかしながら, ベントナイトの主成分であるスメクタイ トの存在下では式(7), (8)の反応は酸化マグネシウムの濃 度に依存し, 酸化マグネシウムがスメクタイトの $10 \%$ 以下 では式(7), (8)の反応は起こらないことが指摘されている 31)。また，スメクタイトは，イオン交換等による $\mathrm{pH}$ 緩衝 能をもつことが知られており, これらのことから, ベント ナイトを多く含む安定液 CASE B-1〜 12 では CASE A-1〜 12 に比べて $\mathrm{pH}$ の上昇が抑えられたと考えられる。
式(7), (8)の反応は遅く ${ }^{32)}$, 文献 ${ }^{31)}$ によると水酸化マグ ネシウムの生成割合は 3 日で $75 \%$ ，28 日で $92 \%$ と報告さ

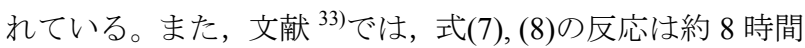
とも報告されている。これらのことは, 安定液作液後の養 生時間が, 吸着効果に大きく影響する可能性があることを 示しており，実施工への適用の際には注意を要する。

\section{5 実污染土による検証実験}

吸着材を添加した安定液懸濁物による重金属等吸着機 能を，実污染土を用いて検証した。使用した試料は表 9 に示す性状の自然由来の As 污染土である。安定液はポリ マー系安定液とし, 吸着材は $\mathrm{MgO}$ と $\mathrm{Al}(\mathrm{OH})_{3}$, 添加量は 5.3 の実験結果の図 17 より $0.5 \%$ と $2.0 \%$ の 2 水準とした。 安定液と試料土を体積比 $1: 1$ で 1 分間の振とう後, ろ過試 験器によりろ過 (ろ過圧 $0.5 \mathrm{MPa}$, 万紙の保留粒子径 $1 \mu \mathrm{m}$ ) を行い, 得られたろ液の As 濃度を測定した。

表 10 に実験結果を示す。実污染土においても $\mathrm{Al}(\mathrm{OH})_{3}$ よりも $\mathrm{MgO}$ の方が吸着機能は高く, $\mathrm{MgO}$ 添加量 $0.5 \%$ で 安定液の As 濃度は地下水環境基準未満に低減した。

以上をまとめると, ベントナイト系安定液は吸着材の添 加によりゲル化しやすいこと, 水酸化アルミニウムは $\mathrm{pH}$ が 9 未満になり, 夏場にバクテリアによる劣化の可能性が あることなどから, 実施工への適用の際の安定液と吸着材 の組み合わせは, ポリマー系安定液に添加剤として $\mathrm{MgO}$ を $0.5 \sim 5 \%$ を添加することが効果的であると考えられる。

\begin{tabular}{|c|c|c|}
\hline 吸着材名 & 添加量 (\%) & As 濃度 $(\mathrm{mg} / \mathrm{L})$ \\
\hline \multirow{2}{*}{$\mathrm{MgO}$} & 0.5 & 0.007 \\
\hline & 2.0 & $<0.005$ \\
\hline \multirow{2}{*}{$\mathrm{Al}(\mathrm{OH})_{3}$} & 0.5 & 0.015 \\
\hline & 2.0 & 0.005 \\
\hline
\end{tabular}

\begin{tabular}{lc}
\multicolumn{2}{c}{ 表 9 試料土の性状等 } \\
\hline \multicolumn{1}{c}{ 測定項目 } & \\
\hline 土袞溶出量 $(\mathrm{mg} / \mathrm{L})$ & 測定值 \\
自然含水比 $(\%)$ & 0.028 \\
土粒子の密度 $\left(\mathrm{g} / \mathrm{cm}^{3}\right)$ & 32.7 \\
\hline
\end{tabular}

\section{6. 安定液の設計手法 · 施工管理手法の考察}

\section{1 安定液の設計手法 1) 配合設計}

本章では, 污染の拡散防止効果を有する安定液の配合設 計について検討する。5 章において, アースドリルによる 掘削では掘削土壌と安定液はおおよそ体積比 $1: 1$ で接触す ることを示した。したがってトリータビリティー試験にお ける固液比は 1 とする。また 5 章の結果から, 安定液はポ リマー系安定液, 吸着材は $\mathrm{MgO}$ で添加率は $0.5,1,2,5 \%$ の 4 水準とする。溶出試験結果から, 添加率一溶出量のグラ フを作成し添加率 $d_{1}$ を算出する。安定液の転用回数を $n$ 回 $(1 \leqq n \leqq 4)$ とし $d_{1} \times n \leqq d_{\mathrm{n}}$ となる $d_{\mathrm{n}}$ を吸着材の添加 
表 11 概算コストの比較

\begin{tabular}{|c|c|c|c|c|c|}
\hline \multirow{2}{*}{$\begin{array}{c}\text { 工法名 } \\
\text { 溶出量レベル }\end{array}$} & \multirow{2}{*}{$\begin{array}{c}\text { 地盤污染対策なし } \\
\text { 場所打ち杭工法 } \\
\text { 基準値未満 }\end{array}$} & \multirow{2}{*}{$\begin{array}{c}\text { 現行の地盤污染対策 } \\
\text { 熏管ヶシシング併用 } \\
\text { 場所打ち杭工法 } \\
\text { 基準値以上 }\end{array}$} & \multicolumn{3}{|c|}{$\begin{array}{c}\text { 本工法 } \\
\text { 重金属吸着安定液による } \\
\text { 場所打ち杭工法 }\end{array}$} \\
\hline & & & 基準値の2倍 & 基準値の5倍 & 基準値の10倍 \\
\hline ケーシング併用掘削エ & & 46 & & & \\
\hline ケーシング内部埋戻しエ & & 15 & & & \\
\hline 杭掘削工 & 92 & 92 & 92 & 92 & 92 \\
\hline 安定液作製～処分費 & 8 & 8 & 9 & 18 & 37 \\
\hline 溶出量確認試験費 & & & 2 & 2 & 2 \\
\hline 工事費計 & 100 & 161 & 103 & 112 & 131 \\
\hline
\end{tabular}

率とする。以上をふまえ, 配合設計のフローチャートの一 例を図 22 に示す。ここで, 吸着量は線形吸着の考え方を 想定している。

5 章で述べたとおり，酸化マグネシウムは水和反応によ り水酸化マグネシウムが生成するが，この反応速度は遅く 作液後の養生日数によって吸着効果が変動する可能性が ある。したがって, 実施工の作業工程にあったトリータビ リティー試験を行う必要がある。

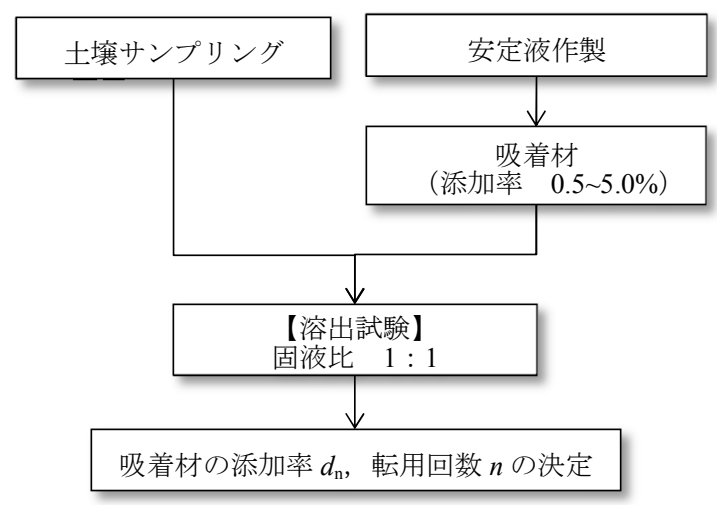

図 22 配合設計の一例

\section{2）設計上の配慮}

アースドリル工法では一般的にドリリングバケットに よる掘削から排土までの 1 サイクルは 10 分程度であり, 土壌はドリリングバケット内に収まったまま地上部に引 き上げられるため, 掘削土壌と安定液とは十分に接触して いるとは言えない。溶出試験における検液作成方法 (毎分 200 回の振とうを 6 時間）に比べて接触時間は短く, 接触 面積も小さいことから, 土壌から安定液への重金属の溶出 量は溶出試験結果よりも小さいと考えられる。また, 3 章 で述べたように安定液と地盤との間の泥膜には一定のろ 過機能をもつと考えられる。したがって，この 2 点につい ては設計上の「安全しろ」と考えることができる。

一方で，前述した吸着材の添加率の検討において，吸着 量は直線的に増加することを前提としているが, 実際には 図 19 からもわかるように非直線系である。したがって, 転用回数と吸着量の関係については, 今後の室内実験なら びに現場実証試験において確認し, 吸着材の添加率の計算 式を改善する必要がある。

設計者はこれらを考慮したうえで, 吸着材の添加率を割 り増しするなど，設計上の配慮が必要である。

\section{2 施工管理手法}

\section{1) 安定液の品質管理}

当工法施工時には，安定液の品質管理試験 ${ }^{34)}$ （比重, ろ過水量, 砂分, ファンネル粘性, $\mathrm{pH}$ ）の際に, 対象之 なる重金属等の濃度を確認する必要がある。特に, 污染地 盤を掘削したのち, 非污染地盤の手前で一旦掘削を中断し， 安定液の液相濃度が地下水環境基準未満であることを確 認することが最も重要である。分析の結果，重金属等の濃 度が地下水環境基準未満であれば掘削を再開し, そうでな ければ安定液の入替えや吸着材の追加等の処置が必要と なる。施工中の重金属等の濃度確認では, 公定法による分 析結果を待って施工を進めることは現実的ではなく, また 3.3 で考察したようにサンプリングからろ過までのタイム ラグによって濃度が低く評価される可能性があることか ら，迅速判定法 ${ }^{35)}$ の採用が望まれる。

\section{2) 安定液の処分}

コンクリートを打設後, コンクリートに置き換わった安 定液は回収槽にいったん貯留される。一般に，この安定液 は品質管理試験ののち修正処理を行ない, 再度掘削に使用 する。再度の使用に耐えないもの，および工事終了時には 産業廃棄物として処分する。しかしながら, 当工法の場合, 吸着機能の修正処理として吸着材の追加はゲル化の恐れ があるためすべきではなく, 今のところ, 配合設計に設定 した転用回数で廃棄処分すべきである。

\section{3) コスト効果}

本工法のコスト効果の概算について表 11 に示す。モデ ルケースとして, 杭径 $2000 \mathrm{~mm}$, 杭長 $30 \mathrm{~m}$, 污染土層厚 $10 \mathrm{~m}(\mathrm{GL} \pm 0 \sim 10 \mathrm{~m})$, 難透水層層厚 $7 \mathrm{~m}(\mathrm{GL}-10 \sim 17 \mathrm{~m})$, 重金属は $\mathrm{As}, \mathrm{F}, \mathrm{Pb}$ が共存し，溶出量は土壌溶出量基準の 2,3,10 倍に設定した。地盤污染対策なしの場合の杭一本 当りの工事費を 100 として, 他のケースの工事費を算出し た。

土壌溶出量が基準值の 2 倍程度であれば, 通常の施工と 同様に安定液の 4 回の転用が可能と思われ, 工事費の増額 は 3\%程度である。土壌溶出量が基準值の 5 倍程度で，安 定液の転用は 2 回に減り, 工事費の増額は $12 \%$ となる。土 壌溶出量が基準值の 10 倍程度になり転用ができない場合 でも, 工事費の増額は 30\%程度で, 現行の地盤污染対策と 比較しても大幅なコスト縮減となる。 


\section{7. まとめ}

污染地盤をアースドリル工法で掘削し, 場所打ち杭を構 築する際，安定液に重金属等（As, F, Pb) が混入する。 このときの, 安定液懸濁物による重金属等の吸着機能を明 らかにした。次に, 安定液に吸着材を添加し, 液相の As,

$\mathrm{F}, \mathrm{Pb}$ の濃度を地下水環境基準未満に低減するための配合 設計手法について実験的に検討を行った。得られた成果は 以下のとおりである。

(1) アースドリル工法で一般に使用されている安定液懸 濁物は, $\mathrm{Pb}$ に対する吸着機能が高いことがわかった。 吸着機能は, 安定液に含まれるベントナイト量と, 安 定液の $\mathrm{pH} （ 8.5 \sim 12.0 ）$ の影響が大きいと考えられる。

(2) ベントナイト系安定液に吸着材を添加することによ り, As，Fに対する吸着機能を持たせることが可能で ある。吸着材は $\mathrm{MgO}$ (添加量 2\%未満), $\mathrm{Al}(\mathrm{OH})_{3}$ (添 加量 5\%未満) であれば適用可能である。

(3) ポリマー系安定液に吸着材を添加することにより, As, F に対する吸着機能を持たせることが可能である。 吸着材は $\mathrm{MgO}$ (添加量 5\%以下), $\mathrm{Al}(\mathrm{OH})_{3}$ (添加量 $5 \%$ 以下）であれば適用可能である。

（4）自然由来程度（土壌溶出量基準の 10 倍以内）の重金 属污染地盤（As，F，Pb）であれば，安定液に適量の 吸着材を添加することで, 安定液本来の性能を保持し ながら, 重金属濃度を地下水環境基準未満に抑え, 污 染の拡散を防止しうることが示唆された。

（5）当工法の工事費は, 対象重金属等の種類, 溶出量など から決まる添加材の量と安定液の転用回数により変 動する。しかしながら, 杭の掘削工事費全体に占める 安定液の割合はわずかであり, 重金属等の溶出量が基 準值の 10 倍程度としても, 工事費の増は 30\%程度で あり, 現行の 2 重管工法と比較するとコスト縮減効果 は大きい。

\section{謝辞}

本研究の遂行にあたり, 京都大学地球環境学堂, 乾徹准 教授に貴重なるご助言をいただきました。また, 室内実験 に関しては株式会社立花マテリアルの久保博氏, 足立達彦 氏，今江和巳氏に多大なるご協力をいただきました。ここ に末筆ながら感謝の意を表します。

1) 環境省 : 土壌污染対策法に基づく調查及び措置に関するガイド ライン（改訂第 2版）, Appendix-12, 2012.

2) 上野雅明 : 廃棄物処分場を通過する道路の建設一東京港臨海大 橋，基礎工，pp.54-56， 2006.

3) 嘉門雅史，勝見武，乾徹，濱田悟 : 鋼管杭打設粘土地盤と杭境 界面における漏水量とその評価，材料，pp.1100-1104, 2005.

4) 菊池喜昭, 森脇武夫, 勝見武, 平尾隆行, 蔦川徹, 服部晃, 岡 本功一, 山田耕一, 佐々木広輝 : 管理型海面廃棄物処分場に打 設する基礎杭が底面遮水地盤に与える影響, 港湾空港技術研究 所資料, No.1252, 2012.

5) 地盤工学会 : 地盤工学・実務シリーズ17 杭基礎の調查・設計・ 施工から検查まで, p. 398, 2004.

6）社団法人日本基礎建設協会 : 場所打ちコンクリート杭の施工と 管理, pp.148-149, 2009.
7) Angelica Naka, Takeshi Katsumi, Toru Inui, Atsushi Takai, Takehiro Ohta: Long-Term Performance of Geosynthetic Clay Liners Used in Acid Rock Drainage Mitigation，ジオシンセティックス論文集，第 26 巻, pp.137-144, 2011.

8) 嘉門雅史, 勝見 武，宮武一都 : セメントベントナイトスラリ 一ウォールの重金属遮へい性能の評価，材料，Vol.49，No.1， pp.22-25, 2000 .

9）山岡伸也, 大坪政美，東 孝寛，Loretta $\mathrm{Li}$ : 粘土ライナーとし てのベントナイト混合土の重金属吸着特性, 農業土木学会論文 集, No.238, pp.43-49, 2005.

10) 和田信一郎：土壌污染対策における粘土科学の役割一粘土基礎 講座 I - , 粘土科学, 第 47 巻, 第 3 号, pp.185-195, 2008.

11) 地盤工学会 : 地盤工学・実務シリーズ 20 地中連続壁工法, pp. 184-185, 2004

12）社団法人日本建築学会:建築工事標準仕様書·同解説 $3 \cdot 4$ JASS3 土工事および山留め工事 JASS4 杭・地業および基礎工事, p.234, 2009.

13）和田信一郎 : 土壤中における重金属類の動態, 地球環境, Vol.15, No.1, pp.15-21, 2010.

14）福士圭介：酸化物による無機陰イオンの吸着一吸着実験による 巨視的吸着挙動とその場分光分析による微視的表面錯体構造一, 粘土科学，第47巻，第3号，pp.121-158, 2008.

15) 日本粘土学会 : 粘土ハンドブック (第三版), p.127, 2009.

16）井上豪・渡口輝 - 玉城不二美 - 仲宗根一哉：「産業廃棄物に含 まれる金属等の検定方法 (環境庁告示 13 号)」で用いるフィル ターの種類が測定結果に及ぼす影響, 沖縄県衛生環境研究所報 第 46 号， 2012.

17) 独立行政法人日本学術振興会 産学協力研究委員会 鉱物新活用 第 111 委員会重金属類と鉱物の相互作用に関するワーキンググ ループ: 重金属污染対策のための鉱物材料ガイドブック, pp.160-161, 2012.

18）日本粘土学会: 粘土ハンドブック (第三版) , p.697， 2009.

19）日本粘土学会 : 粘土ハンドブック (第三版)，pp.127-129，2009.

20) 独立行政法人日本学術振興会 産学協力研究委員会 鉱物新活用 第111 委員会重金属類と鉱物の相互作用に関するワーキンググ ループ : 重金属污染対策のための鉱物材料ガイドブック, pp.98-117, 2012.

21）伊藤健一：合理的な重金属類土壌污染対策のための土壤安全性 簡易診断法の構築, 公益社団法人 JFE21世紀財団 2012 年度技術研 究報告書, pp.133-147, 2012.

22) 佐藤大樹, 五十嵐敏文：トンネル掘削ずりからの砒素等重金属 類含有酸性水の発生とその対策, 第17回地下水・土畩污染とそ の防止対策に関する研究集会, pp.137-141, 2011.

23) 和田祐司 : フッ素含有排水の高度処理, 科学と工業, Vol.76, pp. $557-564,2002$

24) 閒間聖子 : 自然由来重金属問題と建設リサイクル，建設リサイ クル, Vol.65, pp.17-21, 2013.

25) たとえば喜田大三 : 地中連続壁工法（泥水工法）における地盤 掘削用泥水に関寸る研究, 早稲田大学博士論文, pp.169-176, 2013.

26) 和田信一郎 : 土㙥中における重金属類の動態, 地球環境, Vol.15, No.1, p.18, 2010.

27）日本粘土学会 : 粘土ハンドブック（第三版），p.126, 2009.

28）社団法人日本基礎建設協会 : 場所打ちコンクリート杭の施工と 管理, p.154, 2009.

29) たとえば小嶋芳行, 大島史也, 松山祐介, 守屋政彦 : 酸化マグ ネシウムによる重金属イオンの不溶化機構の解明, Journal of Society of Inorganic Materials, Japan, Vol.19, pp.15-22, 2012.

30) 鈴木祐麻, 中村 哲, 片山ひとみ, 新苗正和, 中田英喜, 藤井 啓史, 田坂行雄 : 酸化マグネシウム系不溶化材による七素 $(\mathrm{V})$ 污染土袞の不溶化処理, Journal of MMIJ, Vol.129, pp.650-656, 2013.

31) 森下智貴, 和田信一郎 : 鉱物種の異なる土壌中における酸化マ グネシウムの水和反応とフッ素の不溶化実験, 第20回地下水・ 土壌污染とその防止対策に関する研究集会, pp.122-127, 2014. 
中村·他

32) 独立行政法人日本学術振興会 産学協力研究委員会 鉱物新活用 第111 委員会重金属類と鉱物の相互作用に関するワーキンググ ループ: 重金属污染対策のための鉱物材料ガイドブック, pp.170-171, 2012.

33 ) 矢部太章，福士圭介，伊藤弘志，久保田宗弘，栘谷優輔 : 水溶 液中における酸化マグネシウムの変質挙動, 粘土科学, 第49巻, 第3号, pp.135-140, 2011.
34）社団法人日本基礎建設協会 : 場所打ちコンクリート杭の施工と 管理, pp.264-265, 2009.

35）たとえば熱田真一，稲垣静枝，三原洋一，山田理映子，糸永眞 吾 : 迅速分析法による自然由来の重金属分析事例，第16回地下 水・土壌污染とその防止対策に関する研究集会, pp.585-586, 2010.

(2015.10.30 受付) 


\title{
Sorption of suspended solids in drilling slurry against arsenic, fluorine, and lead
}

\author{
Mitsuo NAKAMURA ${ }^{1}$ and Takeshi KATSUMI ${ }^{2}$
}

1 Haseko Corporation

2 Graduate School of Global Environmental Studies, Kyoto University

\begin{abstract}
Installation of pile foundation at the sites with subsurface contamination is required to prevent cross contamination beneath the aquitard. If the drilling slurry used in cast in place pile installation such as Earth Drill Method exhibits sufficient sorption capacity against chemicals of concern, installation of piles with less complex or expensive method preventing cross contamination will become possible. In this study, batch sorption tests were conducted to assess sorption capacities of suspended solids in the drilling slurry against arsenic (As), fluorine (F), and lead $(\mathrm{Pb})$ for three different concentration levels. Three types of drilling slurry were used, namely polymer-dominant slurry, bentonitic slurry, and a slurry which was obtained from an actual construction site. Effects of the addition of magnesium oxide $(\mathrm{MgO})$ and aluminum hydroxide $(\mathrm{Al}(\mathrm{OH}) 3)$ as the adsorbent were also evaluated. Filtered liquid samples obtained from API (American Petroleum Institute) Filtration Test were subjected to the chemical analysis. Experimental results indicated that suspended solids in drilling slurry exhibited high sorption capacity against lead. Addition of $5 \% \mathrm{MgO}$ or $\mathrm{Al}(\mathrm{OH}) 3$ enhanced the sorption capacity, and consequently satisfied the Japanese environmental quality standards for groundwater. Drilling slurry might function to limit the cross contamination, and advantageous against the sites where natural contamination exists above the aquitard.
\end{abstract}

Key words: sorption, soil contamination, cast in place pile, drilling slurry, cross contamination 